Article

\title{
Stereopermutation on the Putative Structure of the Marine Natural Product Mucosin
}

\author{
Simen G. Antonsen ${ }^{1}$, Harrison Gallantree-Smith ${ }^{1}$, Carl Henrik Görbitz ${ }^{2}$ (D), \\ Trond Vidar Hansen ${ }^{1,3}$, Yngve H. Stenstrøm ${ }^{1}$ (i) and Jens M. J. Nolsøe ${ }^{1, *,+}$ \\ 1 Faculty of Chemistry, Biotechnology and Food Science, Norwegian University of Life Sciences, P.O. Box 5003, \\ 1433 Ås, Norway; simen.antonsen@nmbu.no (S.G.A.); lithium_87@hotmail.co.uk (H.G.-S.); \\ t.v.hansen@farmasi.uio.no (T.V.H.); yngve.stenstrom@nmbu.no (Y.H.S.) \\ 2 Department of Chemistry, University of Oslo, P.O. Box 1033, 0315 Oslo, Norway; c.h.gorbitz@kjemi.uio.no \\ 3 Department of Pharmaceutical Chemistry, University of Oslo, P.O. Box 1068, 0316 Oslo, Norway \\ * Correspondence: jens.mj.nolsoe@nmbu.no; Tel.: +47-6723-2467 \\ † Dedication: Dedicated to Lars Skattebøl on the occasion of his 90th birthday.
}

Received: 19 September 2017; Accepted: 5 October 2017; Published: 13 October 2017

\begin{abstract}
A stereodivergent total synthesis has been executed based on the plausibly misassigned structure of the unusual marine hydrindane mucosin (1). The topological connectivity of the four contiguous all-carbon stereocenters has been examined by selective permutation on the highlighted core. Thus, capitalizing on an unprecedented stereofacial preference of the cis-fused bicycle[4.3.0]non-3-ene system when a Michael acceptor motif is incorporated, copper-mediated conjugate addition furnished a single diastereomer. Cued by the relative relationship reported for the appendices in the natural product, the resulting anti-adduct was elaborated into a probative target structure $\mathbf{1}^{*}$.
\end{abstract}

Keywords: marine hydrindane natural product; asymmetric synthesis; stereodivergent strategy; structural elucidation; eicosanoid

\section{Introduction}

Certain metabolites derived from polyunsaturated fatty acids (PUFAs) play a key role in mammalian physiology, where they orchestrate both inflammatory response as well as the return to homeostasis [1-4]. By combining total synthesis with chemical biology and molecular pharmacology, a number of distinct eicosanoids and docosanoids have been identified, which are active in the cascade elicited by noxious stimuli [5-23]. As a result, natural products with an underlying PUFA motif are of great interest as potential immunomodulators.

Since antiquity, sea dwelling organisms have proven to be a particularly abundant source of new chemical entities, set apart from those found in the terrestrial environment $[24,25]$. Thus, the ancient Phoenicians were renowned for their trading with Tyrian purple from the Murex sea snail [26,27]. Rising above mere prospecting, modern-day discovery, enabled by the advent of powerful analytical instruments and methods, has found a wealth of bioactive compounds in the marine environment [28-34].

Ostensibly, mucosin (1) is a natural product that was isolated from the Mediterranean sponge Reniera mucosa as methyl ester 2 [35]. Formally classified as an eicosanoid, it has been conjectured to originate from arachidonic acid (3), based on the $C_{20}$-architechture (Figure 1). While sharing some noticeable features with the prostane scaffold, the compound differs by having an unusual bicyclic core. Clearly, in the structure proposed for mucosin (1), the characteristic cyclopentane ring is integrated in a cis-fused bicyclo[4.3.0]non-3-ene system. However, turning to the elucidation, the assignment of topology poses a challenge. Though only a small molecule, the structure is compact in terms of the four contiguous stereocentres. In NMR experiments on the isolated methyl ester, pertaining to both 1D- 
and 2D-techniques, the distinguishing resonances/correlations are ensconced in a crowded aliphatic region. Consequently, with the absence of any coupling pattern to corroborate the configuration of the carbocycle, the assignment published by Casapullo et al. does not convince on its own [35].
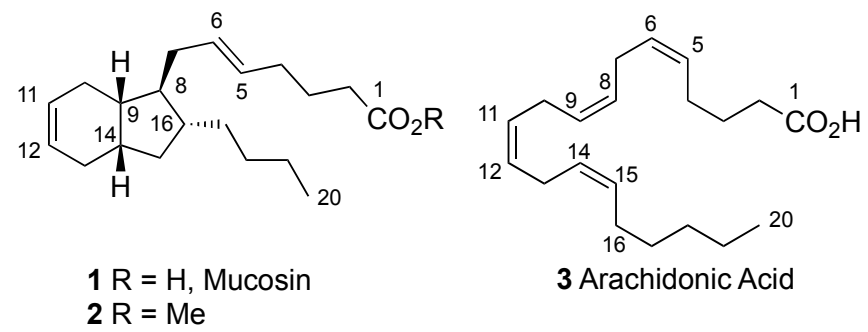

Figure 1. Suggested structure of mucosin and its relation to arachidonic acid.

Fascinated by the structure and the prostane-like motif, we devised a practical, divergent and synthetically unambiguous strategy to establish the proposed stereochemistry. At the end of the campaign, capitalizing on X-ray crystallography to pinpoint the relative arrangement, it was concluded that mucosin (1) does not represent the portrayed compound [36]. In a pursuit to identify the natural product isolated from Reniera mucosa, our intent is to achieve the goal by manipulation of the bicyclo[4.3.0]non-3-ene system. We herein detail synthesis of the mucosin diastereomer $\mathbf{1}^{*}$, demonstrating aspects of the chosen route with regard to stereochemical control (Figure 2). From the point of potential biological activity, the putative structure of mucosin shares some apparent structural similarities with bicyclic prostaglandins. Thus, providing that sufficient amounts could be made available, material could be screened in similar assays. Currently, it is the bearer of unknown properties.

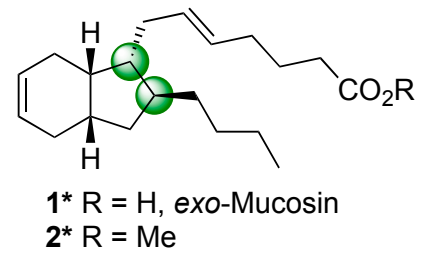

Figure 2. Stereopermutation on the cis-bicyclo[4.3.0]non-3-ene scaffold.

\section{Results and Discussion}

In 2012, Whitby and co-workers reported that they had completed the first total synthesis of antipodal mucosin (ent-1) [37]. Using zirconium induced co-cyclisation as the pivotal feature, the preliminary experimental work led them to conclude that thermodynamic control would favour the relative stereochemistry assigned by Casapullo et al. [35]. Applied to the actual sequence, elaboration of the key zirconacycle afforded a 3:1 mixture of diastereomers [37]. While it was conjectured that the major component could be processed to ent-1, the minor component would in turn yield ent-1*. However, although Whitby and co-workers provided data that aligned with the natural product, the authors of the present paper demonstrated irrefutably, that mucosin is not represented by the relative topological connectivity featured in structure $\mathbf{1}$ [36]. This therefore raised the question as to which diastereomer had been taken on by Whitby and co-workers, and whether mucosin in fact corresponds to structure $\mathbf{1}^{*}$. In order to resolve this pressing issue, we designed a strategy to access structure $\mathbf{1}^{*}$.

A central feature in our divergent strategy (Scheme 1) was to take advantage of the efficient desymmetrization of meso-ketone 4 [36]. (Supplementary Materials pp. S3, S4 provides the synthetic sequence to obtain meso-ketone 4) After a chiral foothold had been established, it would then be a matter of introducing a functional pattern amenable for subsequent stereoiteration. Ideally, in order 
to uncover the topologically deviant point(s), the prerequisite cis-fused keto ester 5 should also be interconvertible with the trans-fused system if need be. However, we first chose to examine the configuration at the appended positions. Thus, along these lines and having previously established a diastereochemical bias, addition of some suitable nucleophile to conjugate ester 7 was judged to follow the precognised trend. By completing the sequence, a new compound $\mathbf{1}^{*}$ with the topology inverted at C8 and C16 would result. Aptly, this could then be named exo-mucosin $\mathbf{1}^{*}$, since the bulky group added during the stereodifferentiating step was projected to occupy the exo face of the bicycle (Figure 3). Once exo-mucosin $\mathbf{1}^{*}$ had been made, the physical data recorded could be compared against those published for the natural product.
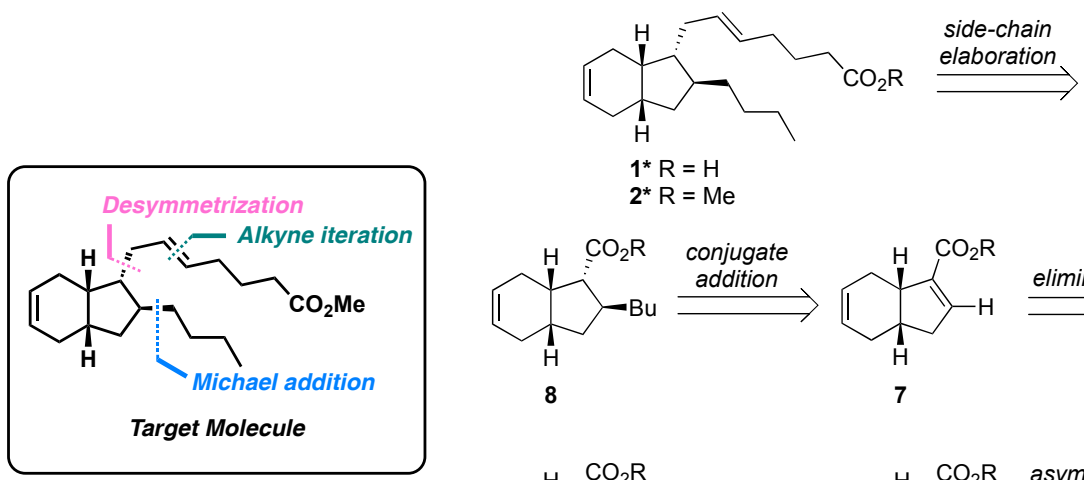

$1^{*} \mathrm{R}=\mathrm{H}$

$2^{*} \mathrm{R}=\mathrm{Me}$
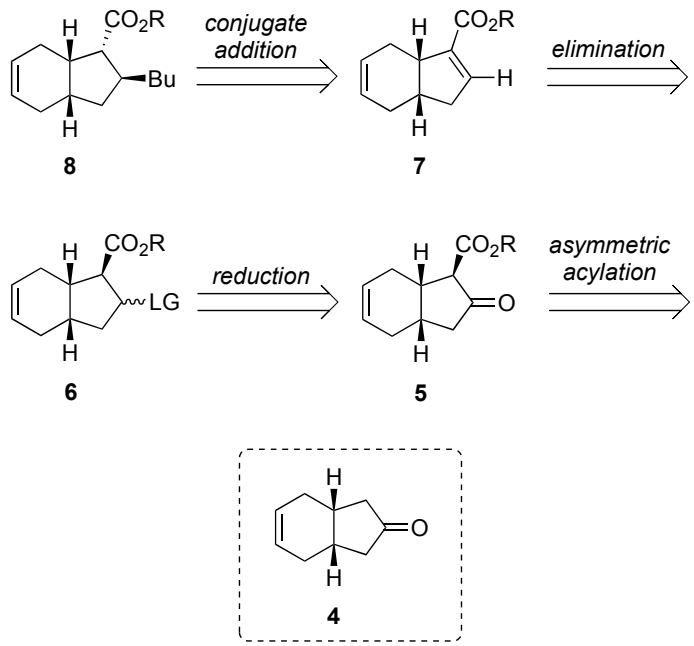

Scheme 1. Key strategic points towards synthesis of exo-mucosin $\left(\mathbf{1}^{*}\right)$.

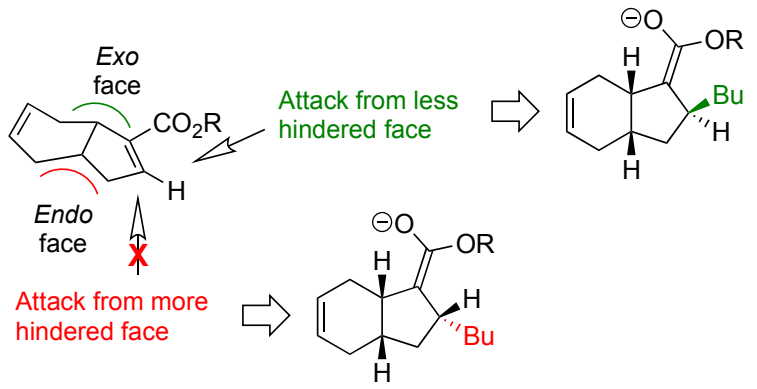

Figure 3. Projected diastereofacial bias in the key conjugate addition.

By the developed protocol, our synthesis commenced with desymmetrization of meso-ketone 4 [36], using Mander's reagent in combination with the lithium amide of (+)-bis[(R)-phenyethyl]amine (Scheme 2). This chiral amide is sometimes also referred to as Simpkins' base [38-40]. Then, with asymmetric keto ester 9 in hand, conjugated ester 10 was prepared by a three-step procedure, involving sequential manipulation of the keto moiety. Accordingly, the ketone in 9 was reduced, whereupon the corresponding alcohol was turned into a mesylate. Finally, the intermediate mesylate was subjected to base-induced elimination, whereby the Michael acceptor motif was produced. 
Having carried out the delineated transformation, the key stereoiterative concept could be tested in the elaboration of conjugated ester 10. While addition to the less hindered exo-face seemed inevitable, the resulting stereochemistry at the ester-appended chiral centre was somewhat uncertain a priori. Simplistically, depending on whether the supervening ester enolate is intercepted by $\mathrm{H}^{+}$ at the equatorial or axial position of $\mathrm{C} 8$, the protonated species will correspond to the kinetic and the thermodynamic product, respectively. Reflecting the ambivalent stereochemical nature of the C8-carbanion, and based on our previous experience [36], conjugate addition to 10 could consequently lead to a mixture of epimers.

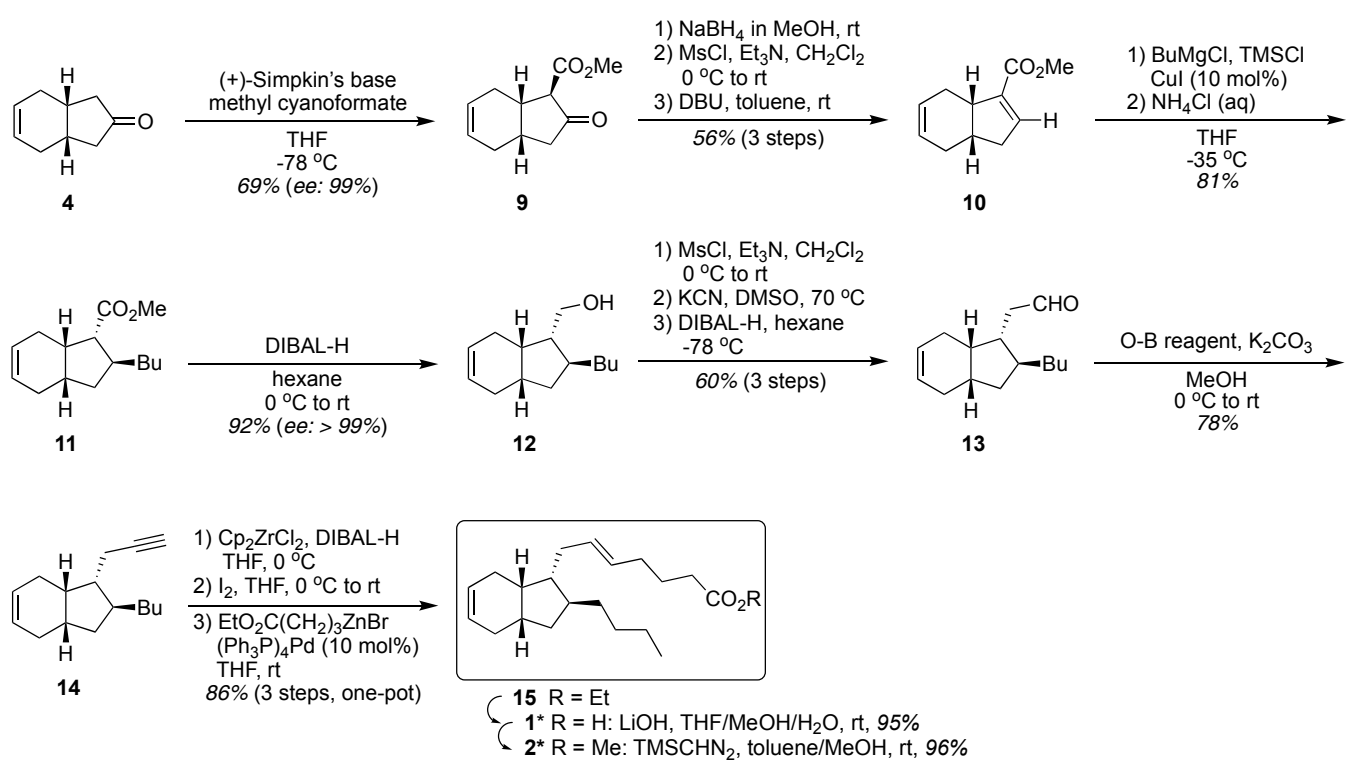

Scheme 2. The total synthesis of exo-mucosin (1*) and its methyl ester $\mathbf{2}^{*}$.

In reality, with $\mathrm{Cu}(\mathrm{I})$-catalysed conjugate addition, using $\mathrm{BuMgCl}$ as nucleophile in the presence of $\mathrm{TMSCl}$, the reaction gave ester $\mathbf{1 1}$ as the sole compound (Scheme 3). Presumably, the Lewis acid takes on dual roles: Not only does TMSCl lower the LUMO of the Michael acceptor, but also stabilizes the ester enolate [41-46]. Hence, ester 11 ought to be the conjectured thermodynamic product. Subsequent reduction provided the corresponding carbinol 12, which could also be readily derivatized for the purpose of X-ray analysis. By obtaining suitable crystals of the dinitrobenzoate 12-DNB, the relative configuration of the four contiguous stereocentres could be established (Figure 4). This also confirmed the exo-facial and thermodynamic preference in the reaction of 10, using the specified conditions. (Supplementary Figure S-74 provides a side perspective of the single crystal X-ray structure 12-DNB).

With the intended topological pattern confirmed, carbinol 12 was taken through a course of four steps to install an alkyne handle by the Ohira-Bestmann protocol [47-50]. For the last step, it may be noted that Taber et al. have provided an interesting alternative to the rather pricy reagent [50]. Although ${ }^{1} \mathrm{H}-\mathrm{NMR}$ of the natural product clearly indicates the presence of an E-alkene [35], the en route aldehyde 13 could also serve as a relay point for Z-selective olefination. However, with the cited observation in mind, alkyne 14 was transformed accordingly to provide the featured E-configured alkenyl ester motif. This was achieved by performing three consecutive reactions in one-pot. Thus, by means of stereospecific hydrometallation [51-55] and halodemetallation [56], alkyne 14 rendered the corresponding E-vinyl halide as substrate for Pd-catalysed cross-coupling with a commercial zinc reagent [57,58]. The target molecule, exo-mucosin $\mathbf{1}^{*}$, was then obtained after hydrolysis of ester $\mathbf{1 5}$. Finally, re-esterification gave methyl ester $2^{*}$, to be compared with the data published by Casapullo et al. [35].

The cis-fused bicyclo[4.3.0]non-3-ene system is not often encountered in nature. Adhering to the supposition that arachidonic acid (3) is the biogenetic origin of mucosin [59-61], the geometry proposed for the core structure invokes a formal disrotatory ring-closure [62]. At a more profound level, 
the machinery leading to the natural product may traverse any number of pericyclic pathways [36]. Of particular interest, though, is the ongoing discussion regarding whether or not enzyme-catalysed Diels-Alder reactions are implicated in biological systems [63]. The preceding biosynthetic transformation of 3 , into a suitable conjugated precursor for cycloaddition, is known to take place in several marine species [59-61,64-77]. However, in all the cases where a Diels-Alderase could be claimed to provide the transformative impetus [78-85], the authors of this paper have found no example of cis-fusion.

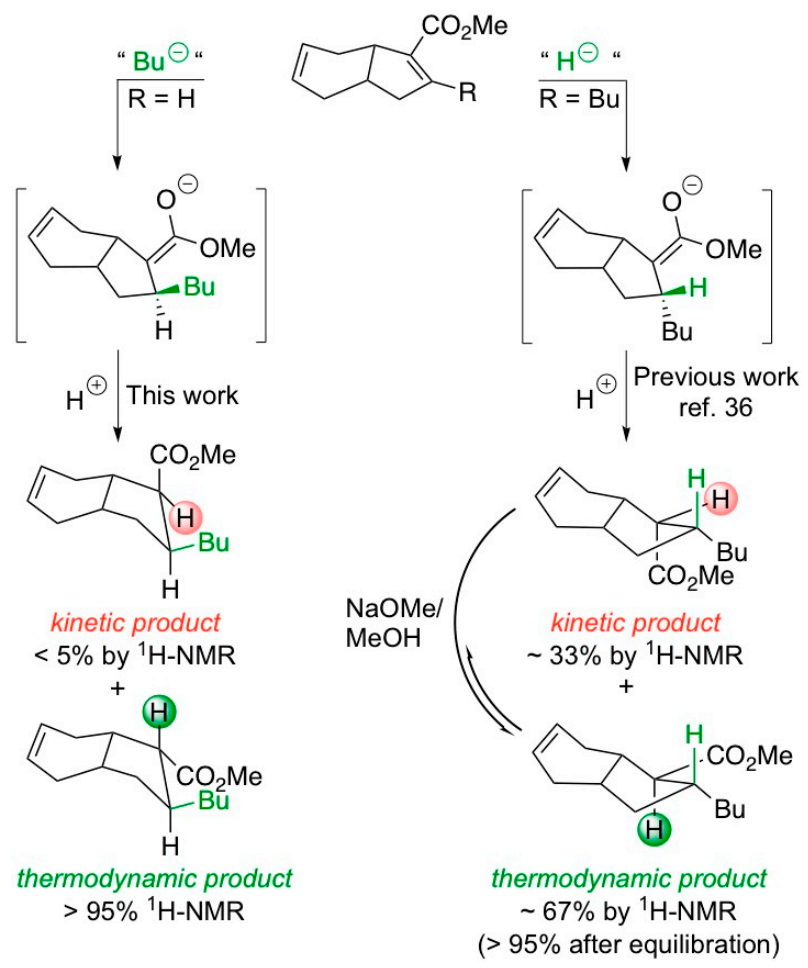

Scheme 3. Observed divergent diastereoselectivity in the conjugate addition to Michael acceptor 10.
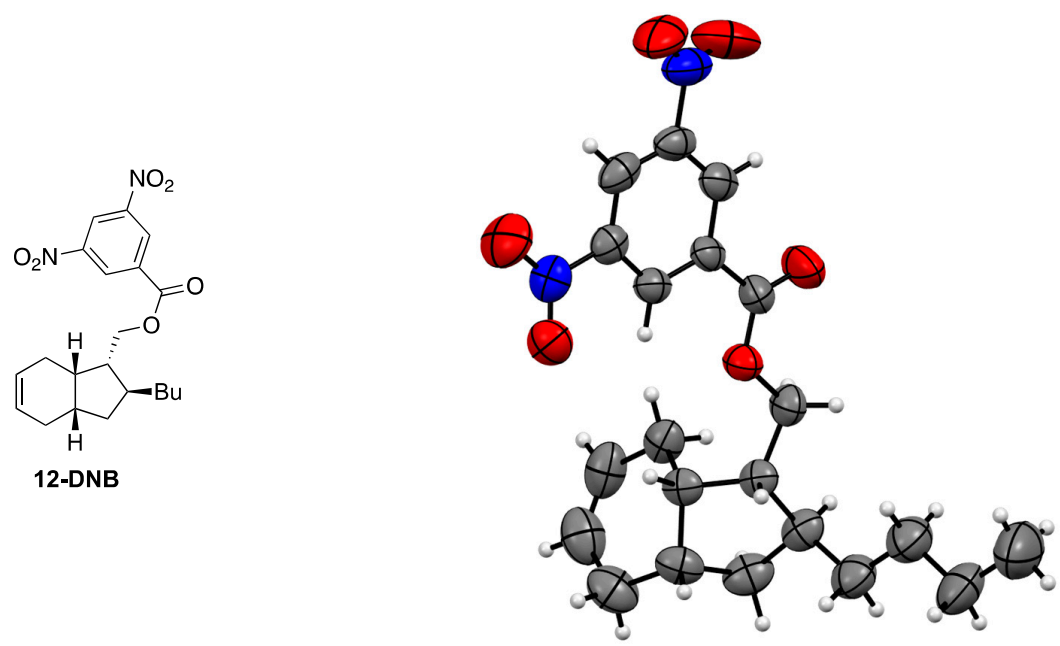

Figure 4. Single crystal X-ray structure obtained from the 3,5-dinitrobenzoate of the advanced intermediate 12 at $298 \mathrm{~K}$. The structure is deposited at Cambridge Crystallographic Data Centre as CCDC 1535632.

Cycloaddition via a non-enzymatic pathway is also possible. Thus, Gerwick has proposed allylic carbocations as conceptual intermediates in the biogenesis of marine carbocyclic oxylipins, such as 
prostaglandin A2 ( $\mathrm{PGA}_{2}$ ) [86-88]. In this sense, arachidonic acid (3) provides a link between mucosin and the prostanoid scaffold, pointing towards a possible mechanism. Yet, for the majority of examples found, the annulation produces a trans-1,2-disubstituted cyclopentane ring [89-94].

Although being an uncommon structural feature, it would be premature to conclude that the cis-fused bicyclo[4.3.0]non-3-ene system was incongruous. Nevertheless, when recordings were made on methyl ester $2^{*}$, the data did not match those reported for the compound isolated from Reniera mucosa. This was most convincingly demonstrated by comparing the ${ }^{13} \mathrm{C}-\mathrm{NMR}$ spectra (Table 1 ): Out of the 20 resonances that are observable for the carbon framework, excluding the methoxy group, 16 display deviating shifts (see also Supplementary Figure S-38). Furthermore, the optical rotation of $2^{*}$ did not only differ in magnitude, but also in sign: While the naturally occurring material and its purported structure 2 have values of $[\alpha]_{D}^{26}=-35.5^{\circ}$ and $-9.8^{\circ}(c=0.8$, hexane), respectively $[35,36]$ the diastereomer $2^{*}$ had an $[\alpha]_{D}^{26}=+64.0^{\circ}$ ( $c=0.8$, hexane). Whitby and co-workers have reported $[\alpha]_{D}^{26}=+38.2^{\circ}(c=0.8$, hexane) for the material obtained via zirconium induced co-cyclisation [37].

Table 1. Comparative ${ }^{13} \mathrm{C}$-NMR of methyl ester $2^{*}$ ( $\delta$-values). ${ }^{\dagger, \ddagger}$

\begin{tabular}{ccccc}
\hline Entry & Casapullo et al. [35] & Whitby et al. [37] & Previous Work [36] & This Work \\
\hline 1 & 174.2 & 174.2 & 174.2 & 174.2 \\
2 & 130.0 & 130.3 & 130.4 & $\mathbf{1 3 1 . 2}$ \\
3 & 129.8 & 129.8 & 129.9 & $\mathbf{1 2 9 . 0}$ \\
4 & 127.0 & 127.3 & $\mathbf{1 2 5 . 3}$ \\
5 & 127.0 & 127.1 & $\mathbf{1 2 6 . 3}$ & $\mathbf{1 2 5 . 1}$ \\
6 & 52.1 & 52.2 & $\mathbf{5 1 . 4}$ & 51.4 \\
7 & 51.4 & 51.4 & 51.0 & $\mathbf{4 1 . 3}$ \\
8 & 47.1 & 47.2 & $\mathbf{4 4 . 0}$ & $\mathbf{3 7 . 2}$ \\
9 & 42.1 & 42.3 & $\mathbf{3 0 . 3}$ & $\mathbf{3 6 . 2}$ \\
10 & 39.9 & 40.1 & 38.1 & $\mathbf{3 5 . 4}$ \\
11 & 36.7 & 37.0 & 37.7 & $\mathbf{3 3 . 4}$ \\
12 & 36.5 & 36.74 & $37 . \mathbf{3}$ & 33.0 \\
13 & 36.4 & 36.68 & 33.4 & 31.9 \\
14 & 33.9 & 31.9 & $\mathbf{3 1 . 0}$ \\
15 & 32.0 & 33.4 & 31.0 & $\mathbf{2 6 . 9}$ \\
16 & 31.7 & 32.4 & 27.8 & $\mathbf{2 4 . 7}$ \\
18 & 31.5 & 31.9 & $\mathbf{2 7 . 7}$ & $\mathbf{2 3 . 0}$ \\
19 & $30.7 \S$ & 31.6 & 24.8 & $\mathbf{2 1 . 7}$ \\
21 & 24.5 & 30.7 & 22.9 & 14.1
\end{tabular}

${ }^{\dagger}$ The italic bold numbers indicate deviating $\delta$-values compared to Ref. [35]. ‡ Upon request, we have not been able to procure the original ${ }^{13} \mathrm{C}$-spectrum from the authors quoted in Ref. [35] for comparison. $\$$ According to communication rendered in the supporting information accompanying Ref. [37], the resonance at $\delta 30.7$ had been omitted in Ref. [35], while an additional signal at $\delta 36.3$ was observed. The data were subsequently revised and this fact is not touched upon in the main paper.

By achieving a rational synthesis of exo-mucosin $2^{*}$, the target selection has been narrowed down. Yet, in terms of the cis-fused bicycle, there are permutants still unaccounted for. However, given the obvious sterical encumbrance of the two remaining syn-diastereomers, they seemed unlikely candidates considering the biogenesis of marine carbocyclic oxylipins [86-88]. Additionally, it is worth noticing that the anti-relationship of the appended groups seems to rest on a sounder foundation: Diagnostic correlations between the C7-methylene group and the C16-proton have been observed by NOESY and ROESY [35]. Furthermore, DFT calculations by Whitby and co-workers on the relative stability of zirconacycles [37], indicate that the anti-geometries are favoured over the syn-geometries. Hence, based on our synthetic endeavours, it was inferred that the natural product named mucosin has a trans-fused bicyclo[4.3.0]non-3-ene ring system and the featured substituents are anti-related.

Albeit that the outlined synthesis did not yield the ultimate target, the sequence provided an answer to a central question: namely, the question about the geometry of the fused bicycle. 
Moreover, taken together with what we have detailed before [36], the current findings have demonstrated a fascinating chemical aspect of the cis-fused bicyclo[4.3.0]non-3-ene scaffold, that unfolds when a Michael acceptor motif is incorporated. Thus, swapping the functional group at the $\beta$-position of the Michael acceptor with the functional group of the Michael donor, a complete inversion of diastereoselectivity was observed. The transformation proved to be doubly orthogonal, as even the stereochemistry at the $\alpha$-position was inverted in the process. Bearing in mind the chosen protocol, it must be assumed that the favoured epimer is not obtained via spontaneous equilibration of the incipient ester enolate anion. Rather, the reactive constellation between $\mathrm{BuMgCl}$ and $\mathrm{TMSCl}$ intercepts the Michael adduct as a silyl ketene acetal; it is therefore in the succeeding protonation of the trapped ester enolate anion that the observed epimeric configuration is established (Scheme 4). The stereoselective protonation of enolates is a concept, which has received a great deal of attention and in its purest form constitutes a biomimetic approach to establish $\alpha$-chirality [95-98]. In our example, the pre-existing topology works in consonance to dictate which face is being protonated.

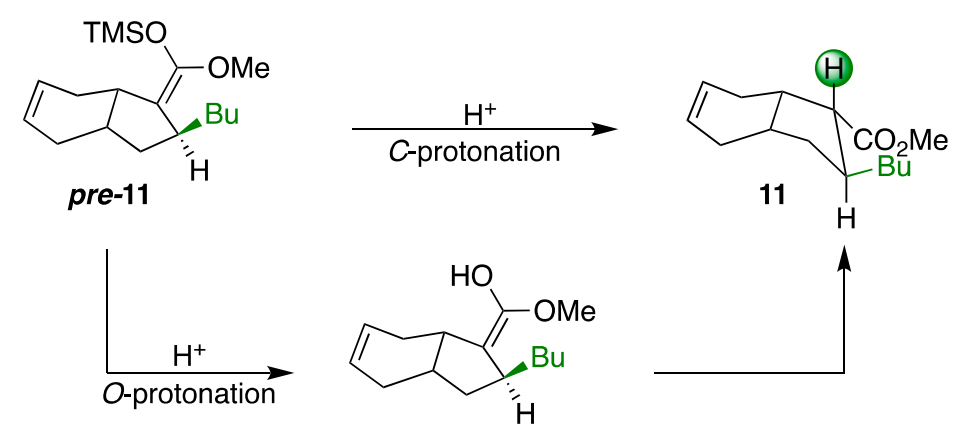

Scheme 4. Silyl ketene acetal as the source of face-selective protonation.

In summary, the conjugate system shown in Scheme 3 (vide supra) displays a remarkable diastereotopic preference, enabling excellent control over the reactive manifold.

\section{Experimental Section}

\subsection{General Information}

All commercially available reagents and solvents were used in the form they were supplied without any further purification. (+)-Bis[(R)-1-phenylethyl]amine hydrochloride (optical purity $\geq 99 \%$ ee by GLC) was purchased from Sigma-Aldrich (St. Louis, MO, USA). The stated yields are based on isolated material. The melting points are uncorrected. Thin layer chromatography was performed on silica gel $60 \mathrm{~F}_{254}$ aluminum-backed plates fabricated by Merck (Kenilworth, NJ, USA). Flash column chromatography was performed on silica gel $60(40-63 \mu \mathrm{m})$ fabricated by Merck. NMR spectra were recorded on a Bruker Ascend $^{\mathrm{TM}} 400$ (Bruker, Billerica, MA, USA) at $400 \mathrm{MHz}$ for ${ }^{1} \mathrm{H}-\mathrm{NMR}$ and at $100 \mathrm{MHz}$ for ${ }^{13} \mathrm{C}-\mathrm{NMR}$. Coupling constants $(J)$ are reported in hertz $(\mathrm{Hz})$ and chemical shifts are reported in parts per million ( $\delta)$ relative to the central residual protium solvent resonance in ${ }^{1} \mathrm{H}-\mathrm{NMR}\left(\mathrm{CDCl}_{3}=\delta 7.27\right)$ and the central carbon solvent resonance in ${ }^{13} \mathrm{C}-\mathrm{NMR}\left(\mathrm{CDCl}_{3}=\delta 77.00 \mathrm{ppm}\right)$. The following abbreviation, appt, has been used to designate an apparent triplet. Mass spectra were recorded at $70 \mathrm{eV}$ on Waters Prospec Q spectrometer (Waters Corporation, Milford, MA, USA) using EI as the method of ionization. IR spectra (4000-600 $\mathrm{cm}^{-1}$ ) were recorded on a Perkin-Elmer Spectrum BX series FT-IR spectrophotometer (Waltham, MA, USA) using a reflectance cell (HATR). Optical rotations were measured using a $1 \mathrm{~mL}$ cell with a $1.0 \mathrm{dm}$ path length on a Perkin Elmer 341 polarimeter using the stated solvents. Determination of enantiomeric excess was performed by GLC on an Agilent Technologies 7820A GC instrument (Agilent Technologies, Santa Clara, CA, USA) with split (1:30) injection, FID detector and equipped with a chiral stationary phase (Agilent J\&W GC columns, CP-Chirasil-DEX CB, $25 \mathrm{~m}, 0.25 \mathrm{~mm}, 0.25 \mu \mathrm{m}$ ) applying the conditions stated. X-ray crystallography was performed on a Bruker D8 Venture diffractometer 
with InCoatec ImuS Microfocus radiation source and Photon 100 CMOS detector. Data collection with Apex2 [99], data integration and cell refinement with SAINT,1 absorption correction by SADABS [99], structure solution with SHELXT [100], structure refinement with SHELXL [101]. Molecular graphics from Mercury [102].

\subsection{Synthesis of Keto Ester 9}

(+)-Bis[(R)-1-phenylethyl]amine hydrochloride (2.5 g, $9.60 \mathrm{mmol}, 1.58$ equiv.) was added in one portion to dry THF $(10 \mathrm{~mL})$ at ambient temperature and stirred for $5 \mathrm{~min}$. The stirring suspension was then cooled to $-78{ }^{\circ} \mathrm{C}$ and $\mathrm{BuLi}(2.5 \mathrm{M}$ in hexane) $(7.67 \mathrm{~mL}, 19.18 \mathrm{mmol}, 3.16$ equiv.) was added dropwise. The suspension changed colour from cloudy white to pale orange. After stirring at $-78{ }^{\circ} \mathrm{C}$ for $15 \mathrm{~min}$ the suspension was warmed to ambient temperature whereby a transparent yellow solution was formed. This recooled to $-78^{\circ} \mathrm{C}$ and meso-(1S,6R)-bicyclo[4.3.0]non-3-ene-8-one 4 (0.826 g, $6.07 \mathrm{mmol}$, 1.0 equiv.) was added dropwise over $10 \mathrm{~min}$ in dry THF $(10 \mathrm{~mL})$. This mixture was then stirred for $45 \mathrm{~min}$ whereby a purple colour evolved. Methyl cyanoformate $(0.96 \mathrm{~mL}, 12.14 \mathrm{mmol}, 2.0$ equiv. $)$ was then added dropwise over $5 \mathrm{~min}$. and the mixture immediately turned bright yellow in colour. This mixture was left stirring for $2.5 \mathrm{~h}$ and then quenched by addition of $\mathrm{H}_{2} \mathrm{O}(2 \mathrm{~mL})$ at $-78{ }^{\circ} \mathrm{C}$. The mixture was then warmed to r.t. and extracted with EtOAc $(2 \times 50 \mathrm{~mL})$. The resulting organic layer was then washed with $\mathrm{H}_{2} \mathrm{O}(2 \times 100 \mathrm{~mL}), 0.5 \mathrm{M} \mathrm{HCl}(1 \times 100 \mathrm{~mL})$ and brine $(1 \times 100 \mathrm{~mL})$. The organic layer was then dried over $\mathrm{MgSO}_{4}$, filtered and concentrated in vacuo. The resulting crude keto ester was purified by column chromatography (hexane/EtOAc 5:1) to form a colourless oil. This oil was then recrystallised from hexane at $0{ }^{\circ} \mathrm{C}$, filtered and air dried to obtain the compound 9 as white crystals. All spectroscopic and physical data were in full agreement with those reported in the literature [103]. Yield: $0.812 \mathrm{~g}$ $(69 \%) ;[\alpha]_{D}^{26}=-161^{\circ}\left(c=0.1, \mathrm{CHCl}_{3}\right) ;{ }^{1} \mathrm{H}-\mathrm{NMR}\left(400 \mathrm{MHz}, \mathrm{CDCl}_{3}\right): \delta 5.73-5.66(\mathrm{~m}, 2 \mathrm{H}), 3.76(\mathrm{~s}, 3 \mathrm{H})$, $3.04(\mathrm{~d}, J=11.1 \mathrm{~Hz}, 1 \mathrm{H}), 2.88-2.83(\mathrm{~m}, 1 \mathrm{H}), 2.52-2.38(\mathrm{~m}, 3 \mathrm{H}), 2.33-2.21(\mathrm{~m}, 2 \mathrm{H}), 2.04(\mathrm{dd}, J=1.9,18.2 \mathrm{~Hz}$, 1H), 1.67-1.61 (m, 1H); ${ }^{13} \mathrm{C}-\mathrm{NMR}\left(100 \mathrm{MHz}, \mathrm{CDCl}_{3}\right): \delta 211.6,169.7,124.9,123.9,57.7,52.4,46.6,37.3$, 29.7, 26.8, 25.3; IR (neat, cm ${ }^{-1}$ ) 3034 (w), 2945 (m), 2908 (m), 2837 (w), 1751 (s), 1718 (s) 1656 (w) 1433 (s) 1404 (m); HRMS (EI+): Exact mass calculated for $\mathrm{C}_{11} \mathrm{H}_{14} \mathrm{O}_{3}[\mathrm{M}]^{+}:$194.0943 found 194.0933; m.p.: 59-61 ${ }^{\circ} \mathrm{C}$; TLC (hexane/EtOAc 4:1, $\mathrm{KMnO}_{4}$ stain): $\mathrm{R}_{\mathrm{f}}=0.42$.

\subsection{Synthesis of Michael Acceptor $\mathbf{1 0}$}

\subsubsection{Synthesis of $\alpha$-Hydroxy Ester pre-10a}

To stirring solution of 9 (1.40 g, $7.21 \mathrm{mmol}, 1.0$ equiv.) in $\mathrm{MeOH}(50 \mathrm{~mL})$ at $0{ }^{\circ} \mathrm{C}$ was added $\mathrm{NaBH}_{4}$ $(0,410 \mathrm{~g}, 10.8 \mathrm{mmol}, 1.5$ equiv.). The reaction was monitored by TLC and was deemed complete after $1 \mathrm{~h}$. Then, dilute aq. $\mathrm{HCl}(10 \mathrm{~mL}, 1 \mathrm{M})$ was added drowise at $0{ }^{\circ} \mathrm{C}$. The quenched reaction was concentrated in vacuo to afford a crude mixture. This was poured over $\mathrm{Et}_{2} \mathrm{O}(50 \mathrm{~mL})$, whereupon water $(50 \mathrm{~mL})$ was added. The organic layer was separated and the aqueous layer was extracted with $\mathrm{Et}_{2} \mathrm{O}(2 \times 50 \mathrm{~mL})$. The organic layers were combined, washed with brine $(1 \times 100 \mathrm{~mL})$, dried over $\mathrm{MgSO}_{4}$, filtered and concentrated in vacuo to afford a colourless, oily, residue. The crude was purified by column chromatography on silica (hexane/EtOAc 7:3) to afford the C8-epimeric compound pre-10a as colourless oil. Yield: $1.07 \mathrm{~g}(76 \%) ;{ }^{1} \mathrm{H}-\mathrm{NMR}\left(400 \mathrm{MHz}, \mathrm{CDCl}_{3}\right)$ : $\delta 5.81-5.71(\mathrm{~m}, 2 \mathrm{H}), 4.57-4.39(\mathrm{~m}, 1 \mathrm{H}), 3.73(\mathrm{~s}, 3 \mathrm{H})$, 2.65-2.50 (m, 1H), 2.38-2.10 (m, 6H), 2.10-1.84 (m, 2H), 1.52-1.42 (m, 1H); ${ }^{13} \mathrm{C}-\mathrm{NMR}\left(100 \mathrm{MHz}, \mathrm{CDCl}_{3}\right)$ : $\delta 175.5$ (major), 174.8 (minor), 127.5 (minor), 126.7 (minor), 126.6 (major), 125.6 (major), 75.3 (major), 73.0 (minor), 57.3 (major), 53.9 (minor), 51.8 (major), 51.7 (minor), 42.1 (minor), 40.9 (major), 39.0 (major), 38.0 (minor), 34.0 (minor), 33.6 (major), 27.9 (minor), 27.7 (major), 26.3 (major), 26.2 (minor); IR (neat, $\mathrm{cm}^{-1}$ ) 3439 (br), 3026 (w), 2914 (w), 2841 (w), 1712 (s), 1438 (m); HRMS (EI+): Exact mass calculated for $\mathrm{C}_{11} \mathrm{H}_{16} \mathrm{O}_{3}$ $[\mathrm{M}]^{+}:$196.1099, found 196.1087; TLC (hexane/EtOAc 4:1, $\mathrm{KMnO}_{4}$ stain): $\mathrm{R}_{\mathrm{f}}=0.30$. 


\subsubsection{Synthesis of Mesylate pre-10b}

To a stirring solution of C8-epimer pre-10a (1.07 g, $5.45 \mathrm{mmol}, 1.0$ equiv.) in dry $\mathrm{CH}_{2} \mathrm{Cl}_{2}(50 \mathrm{~mL})$ at ambient temperature was added $\mathrm{Et}_{3} \mathrm{~N}(1.14 \mathrm{~mL}, 8.18 \mathrm{mmol}, 1.5$ equiv. $)$ in a dropwise manner. The resulting mixture was left stirring for $5 \mathrm{~min}$. and then cooled to $0{ }^{\circ} \mathrm{C}$. Subsequently, methanesulfonyl chloride $(0.51 \mathrm{~mL}, 6.59 \mathrm{mmol}, 1.2$ equiv.) was added in a dropwise manner and the reaction mixture was left stirring for $10 \mathrm{~min}$. with continued cooling. Then, the cooling was discontinued and the reaction mixture was allowed to attain ambient temperature overnight. At this point the reaction mixture had turned from colourless to yellow. Brine $(20 \mathrm{~mL})$ was added in a dropwise manner and the volatiles were removed in vacuo. The resulting yellow liquid was poured over EtOAc $(50 \mathrm{~mL})$ and satd. aq. $\mathrm{NaHCO}_{3}$ $(50 \mathrm{~mL})$ was added. The organic layer was separated and the aqueous layer was extracted with EtOAc $(2 \times 50 \mathrm{~mL})$. The organic layers were combined and washed with brine $(1 \times 100 \mathrm{~mL})$, dried over $\mathrm{MgSO}_{4}$, filtered and concentrated in vacuo to afford a yellow, oily, residue. The crude was purified by column chromatography on silica (hexane/EtOAc 4:1) to afford the C8-epimeric compound pre-10b as a yellow oil. Yield: $1.16 \mathrm{~g}(77 \%) ;{ }^{1} \mathrm{H}-\mathrm{NMR}\left(400 \mathrm{MHz}, \mathrm{CDCl}_{3}\right) \delta 5.81-5.77(\mathrm{~m}, 0.3 \mathrm{H}, \mathrm{minor}),(\mathrm{m}, 1.7 \mathrm{H}$, major), 5.37-5.31 (m, 1H), 3.74 (s, 2.6H, major), 3.72 (s, 0.4H, minor), 3.01 (s, 2.6H, major), 2.96 (s, $0.4 \mathrm{H}$, minor), $2.88-2.82(\mathrm{~m}, 1 \mathrm{H}), 2.4 .06(\mathrm{~m}, 6 \mathrm{H}), 2.02-1.87(\mathrm{~m}, 1 \mathrm{H}), 1.86-1.78(\mathrm{~m}, 1 \mathrm{H}) ;{ }^{13} \mathrm{C}-\mathrm{NMR}(100 \mathrm{MHz}$, $\left.\mathrm{CDCl}_{3}\right) \delta 173.9,127.3$ (minor), 126.8 (minor), 125.6 (major), 124.4 (major), 83.9 (major), 83.8 (minor), 54.6 (major), 53.6 (minor), 52.2 (major), 51.9 (minor), 40.9 (minor), 39.8 (major), 39.1 (major), 38.3 (minor), 37.9 (major), 36.4 (minor), 33.9 (major), 33.5 (minor), 27.6 (minor), 26.6 (major), 26.0 (minor), 25.4 (major); IR (neat, cm ${ }^{-1}$ ) 3031 (w), 2942 (w), 2847 (w), 1734 (s), 1438 (w), 1354 (s); HRMS (EI+): Exact mass calculated for $\mathrm{C}_{12} \mathrm{H}_{18} \mathrm{O}_{5} \mathrm{~S}[\mathrm{M}]^{+}:$274.0875, found 274.0865; TLC (hexane/EtOAc 4:1, $\mathrm{KMnO}_{4}$ stain): $\mathrm{R}_{\mathrm{f}}=0.45$.

\subsubsection{Synthesis of Michael Acceptor 10}

To a stirring solution of C8-epimer pre-10b (1.40 g, $5.10 \mathrm{mmol}, 1.0$ equiv.) in dry toluene $(30 \mathrm{~mL})$ at ambient temperature was added DBU (1.73 mL, $11.6 \mathrm{mmol}, 2.3$ equiv.) in a dropwise manner over $5 \mathrm{~min}$. The reaction mixture was stirred overnight at the stated conditions. Having deemed the reaction complete by TLC, water $(10 \mathrm{~mL})$ and dilute aq. $\mathrm{HCl}(10 \mathrm{~mL}, 0.5 \mathrm{M})$ was added. The resulting mixture was poured over $\mathrm{Et}_{2} \mathrm{O}(20 \mathrm{~mL})$ and the organic layer was separated. The aqueous layer was extracted with $\mathrm{Et}_{2} \mathrm{O}(2 \times 30 \mathrm{~mL})$. The organic layers were combined, washed in succession with water $(1 \times 50 \mathrm{~mL})$ and brine $(1 \times 50 \mathrm{~mL})$, dried over $\mathrm{MgSO}_{4}$, filtered and concentrated in vacuo to obtain a oily residue. The crude was purified by column chromatography on silica (hexane/EtOAc 9:1) to afford the compound 10 as colourless oil. Yield: $0.866 \mathrm{~g},(95 \%) ;[\alpha]_{D}^{26}=+180^{\circ}\left(c=0.8, \mathrm{CHCl}_{3}\right)$; ${ }^{1} \mathrm{H}-\mathrm{NMR}\left(400 \mathrm{MHz}, \mathrm{CDCl}_{3}\right) \delta$ 6.80-6.69 (m, 1H), 5.95-5.84 (m, 1H), 5.84-5.74 (m, 1H), $3.74(\mathrm{~s}, 3 \mathrm{H})$, 3.04-3.92 (m, 1H), 2.67-2.51 (m, 2H), 2.50-2.36 (m, 1H), 2.34-2.12 (m, 2H), 2.00-1.82 (m, $2 \mathrm{H}) ;{ }^{13} \mathrm{C}-\mathrm{NMR}$ $\left(100 \mathrm{MHz}_{,} \mathrm{CDCl}_{3}\right) \delta 165.6,143.5,140.8,128.3,127.0,51.2,41.2,39.4,36.0,27.8,26.6$; IR (neat, $\left.\mathrm{cm}^{-1}\right)$ $3031(\mathrm{w}), 2931(\mathrm{w}), 2841(\mathrm{w}), 1712(\mathrm{~s}), 1628(\mathrm{w}), 1438$ (m); HRMS (EI+): Exact mass calculated for $\mathrm{C}_{11} \mathrm{H}_{14} \mathrm{O}_{2}[\mathrm{M}]^{+}:$178.0994, found 178.1000; TLC (hexane/EtOAc 4:1, $\mathrm{KMnO}_{4}$ stain): $\mathrm{R}_{\mathrm{f}}=0.60$.

\subsection{Synthesis of Michael Adduct $\mathbf{1 1}$}

To a solution of Michael acceptor $10(0.421 \mathrm{~g}, 2.36 \mathrm{mmol}, 1.0$ equiv. $)$ in dry THF (20 mL) at $-35^{\circ} \mathrm{C}$ was added in succession $\mathrm{CuI}(0.045 \mathrm{~g}, 0.24 \mathrm{mmol}, 0.1$ equiv. $)$ and TMSCl $(0.641 \mathrm{~g}, 0.75 \mathrm{~mL}$, $5.90 \mathrm{mmol}, 2.5$ equiv.). The resulting slightly heterogenous mixture caused by suspended CuI was stirred for $5 \mathrm{~min}$, whereupon $\mathrm{BuMgCl}$ (2.0 M in THF) (2.36 mL, $4.72 \mathrm{mmol}, 2.0$ equiv.) was added in a dropwise manner during the course of $2 \mathrm{~h}$, maintaining the temperature between at $-35^{\circ} \mathrm{C}$. Initial colours cycled between clear and yellow, but gradually took a transient purple hue while reverting to clear. Upon completing the addition, the purple colour persisted (cloudy amethyst). At this point, TLC revealed that the starting material had been consumed. The reaction was treated with aq. satd. $\mathrm{NH}_{4} \mathrm{Cl}(5 \mathrm{~mL})$ and diluted with $\mathrm{Et}_{2} \mathrm{O} /$ water $(30 \mathrm{~mL}, 2: 1)$. The phases were separated and 
the aq. phase was extracted with $\mathrm{Et}_{2} \mathrm{O}(3 \times 20 \mathrm{~mL})$. The combined org. phases were washed with brine $(15 \mathrm{~mL})$, dried over $\mathrm{MgSO}_{4}$, filtered and the solvent was evaporated in vacuo. The residue was purified by column chromatography on silica (hexane/EtOAc 90:10) to afford compound $\mathbf{1 1}$ as a colourless oil. Yield: $0.496 \mathrm{~g}(81 \%) ;[\alpha]_{D}^{26}=+63^{\circ}\left(c=0.8, \mathrm{CHCl}_{3}\right) ;{ }^{1} \mathrm{H}-\mathrm{NMR}\left(400 \mathrm{MHz}, \mathrm{CDCl}_{3}\right) \delta 5.66-5.56(\mathrm{~m}, 2 \mathrm{H})$, $3.67(\mathrm{~s}, 3 \mathrm{H}), 2.58-2.46(\mathrm{~m}, 2 \mathrm{H}), 2.36-2.16(\mathrm{~m}, 3 \mathrm{H}), 1,95-1.68(\mathrm{~m}, 4 \mathrm{H}), 1.45-1.35(\mathrm{~m}, 2 \mathrm{H}), 1.35-1.15(\mathrm{~m}, 5 \mathrm{H})$, $0.87(\mathrm{t}, J=7.0 \mathrm{~Hz}, 3 \mathrm{H}) ;{ }^{13} \mathrm{C}-\mathrm{NMR}\left(100 \mathrm{MHz}, \mathrm{CDCl}_{3}\right) \delta 174.8,124.7,124.6,56.0,51.3,38.9,37.4,36.8,36.0$, 35.3, 30.4, 26.5, 22.8, 22.6, 14.1; IR (neat, $\mathrm{cm}^{-1}$ ) 3020 (w), 2925 (m), 1734 (s); HRMS (EI+): Exact mass calculated for $\mathrm{C}_{15} \mathrm{H}_{24} \mathrm{O}_{2}[M]^{+}: 236.1776$, found 236.1763; TLC (hexanes/EtOAc 80:20, $\mathrm{KMnO}_{4}$ stain): $\mathrm{R}_{\mathrm{f}}=0.70$.

\subsection{Synthesis of Carbinol $\mathbf{1 2}$}

Michael adduct 11 (0.496 g, $2.10 \mathrm{mmol}, 1.0$ equiv.) was dissolved in hexane (10 mL) at ambient temperature and stirred for $5 \mathrm{~min}$. The solution was then cooled to $0{ }^{\circ} \mathrm{C}$ and DIBAL-H (1M in hexane) (4.2 $\mathrm{mL}, 4.20 \mathrm{mmol}, 2.0$ equiv.) was added dropwise over $5 \mathrm{~min}$. The reaction was then left to warm to r.t. After $1 \mathrm{~h}$ the reaction was cooled back to $0{ }^{\circ} \mathrm{C}$ and quenched with sat. aq. $\mathrm{NH}_{4} \mathrm{Cl}(5 \mathrm{~mL})$. The reaction mixture was allowed to warm to ambient temperature whereby a cloudy suspension occurred. This suspension was poured over sat. aq. $\mathrm{NH}_{4} \mathrm{Cl}(20 \mathrm{~mL})$ and the organic layer separated. The aqueous layer was extracted with EtOAc $(2 \times 50 \mathrm{~mL})$ and the organic layers combined, washed with $\mathrm{H}_{2} \mathrm{O}$ $(1 \times 100 \mathrm{~mL})$, brine $(1 \times 100 \mathrm{~mL})$, dried over $\mathrm{MgSO}_{4}$, filtered and concentrated in vacuo to give a crude cloudy oil. This was then purified by column chromatography on silica (hexane/EtOAc 95:5) to afford compound 12 as a colourless oil. Yield: $0.400 \mathrm{~g},(92 \%) ;[\alpha]_{D}^{26}=+104^{\circ}\left(c=0.8, \mathrm{CHCl}_{3}\right) ;{ }^{1} \mathrm{H}-\mathrm{NMR}(400 \mathrm{MHz}$, $\left.\mathrm{CDCl}_{3}\right)$ 5.77-5.51 (m, 2H), 3.77-3.58 (m, 2H), 2.38-2.22 (m, 1H), 2.22-2.05 (m, 2H), 2.05-1.71 (m, 4H) 1.71-1.52 (m, 2H), 1.52-1.35 (2H) 1.35-1.14 (m, 6H), $0.88(\mathrm{t}, J=7.1 \mathrm{~Hz}, 3 \mathrm{H}) ;{ }^{13} \mathrm{C}-\mathrm{NMR}\left(100 \mathrm{MHz}, \mathrm{CDCl}_{3}\right)$ $\delta$ 125.3, 124.9, 63.3, 53.7, 38.1, 36.8, 36.3, 35.5, 35.4, 30.8, 26.6, 22.9, 21.6, 14.1; IR (neat, $\mathrm{cm}^{-1}$ ) 3328 (br.), 3020 (w), 2925 (s); HRMS (EI+): Exact mass calculated for $\mathrm{C}_{14} \mathrm{H}_{24} \mathrm{O}[M]^{+}$: 208.1827, found 208.1832; TLC (hexane/EtOAc 4:1, $\mathrm{KMnO}_{4}$ stain): $\mathrm{R}_{\mathrm{f}}=0.40$. The enantiomeric excess was determined by chiral GLC analysis (CP-Chirasil-DEX CB, using the following program: $60{ }^{\circ} \mathrm{C}(45 \mathrm{~min})-1$ degrees $/ \mathrm{min}$ to $\left.160{ }^{\circ} \mathrm{C}-160{ }^{\circ} \mathrm{C}(5 \mathrm{~min})\right): t_{r}\left(e_{1}\right.$, major $)=65.08 \mathrm{~min}$ and $t_{r}\left(e_{2}\right.$, minor $)=65.67 \mathrm{~min} ; e e:>99 \%$ [104] .

\subsection{Synthesis of 3,5-Dinitrobenzoate 12-DNB}

To a stirring solution of carbinol $12(0.129 \mathrm{~g}, 0.546 \mathrm{mmol}, 1.0$ equiv. $)$ in dry DCM $(20 \mathrm{~mL})$ was added $\mathrm{Et}_{3} \mathrm{~N}\left(0.23 \mathrm{~mL}, 1.64 \mathrm{mmol}, 3.0\right.$ equiv.) dropwise. The solution was then cooled to $0{ }^{\circ} \mathrm{C}$ and 3,5-dinitrobenzoyl chloride $(0.215 \mathrm{~g}, 0.933 \mathrm{mmol}, 1.7$ equiv.) was added in one portion. The reaction was slowly warmed to ambient temperature and monitored by TLC until completion. After $2 \mathrm{~h}$, the reaction mixture was poured over $\mathrm{H}_{2} \mathrm{O}(10 \mathrm{~mL})$ and the organic layer separated. The aqueous layer was then extracted with DCM $(2 \times 10 \mathrm{~mL})$ and the organic layers combined. The organic layers were then washed with $\mathrm{H}_{2} \mathrm{O}(1 \times 30 \mathrm{~mL})$, brine $(1 \times 30 \mathrm{~mL})$, dried with $\mathrm{MgSO}_{4}$, filtered and concentrated in vacuo to form a crude orange oil. This was purified by column chromatography on silica (hexane/EtOAc, 95:5) to afford the compound 12-DNB as a white powder. Yield: $0.193 \mathrm{~g}(88 \%),[\alpha]_{D}^{26}=+42^{\circ}$ $\left(c=0.8, \mathrm{CHCl}_{3}\right) ;{ }^{1} \mathrm{H}-\mathrm{NMR}\left(400 \mathrm{MHz}, \mathrm{CDCl}_{3}\right) \delta 9.23(\mathrm{t}, J=2.2 \mathrm{~Hz}, 1 \mathrm{H}), 9.14(\mathrm{~d}, J=2.2 \mathrm{~Hz}$, $2 \mathrm{H}), 5.70-5.61(\mathrm{~m}, 2 \mathrm{H}), 4.49(\mathrm{~s}, 1 \mathrm{H}), 4.47(\mathrm{~d}, J=1.9 \mathrm{~Hz}, 1 \mathrm{H}), 2.37-2.10(\mathrm{~m}, 4 \mathrm{H}), 2.02-1.88(\mathrm{~m}, 2 \mathrm{H})$, 1.88-1.68 (m, 3H), 1.58-1.43 (m, 2H), $1.40-1.23(\mathrm{~m}, 5 \mathrm{H}), 0.89(\mathrm{t}, J=6.7 \mathrm{~Hz}, 3 \mathrm{H}) ;{ }^{13} \mathrm{C}-\mathrm{NMR}(100 \mathrm{MHz}$, $\left.\mathrm{CDCl}_{3}\right) \delta 162.5,148.7,134.1,129.3,125.4,124.3,122.3,67.7,49.5,38.6,36.9,36.7,35.5,35.4,30.8,26.5$, 22.9, 21.8, 14.1; IR (neat, $\mathrm{cm}^{-1}$ ) $3098(\mathrm{w}), 3020$ (w), 2931 (m), 1723 (s), 1538 (s); HRMS (EI+): Exact mass calculated for $\mathrm{C}_{21} \mathrm{H}_{26} \mathrm{~N}_{2} \mathrm{O}_{6}[M]^{+}: 402.1791$, found 402.1797; m.p.: $117^{\circ} \mathrm{C}$; TLC (hexane/EtOAc 4:1, $\mathrm{KMnO}_{4}$ stain): $\mathrm{R}_{\mathrm{f}}=0.75$. [105] 


\subsection{Synthesis of Aldehyde $\mathbf{1 3}$}

\subsubsection{Synthesis of Mesylate pre-13a}

To a stirring solution of carbinol $12(0.400 \mathrm{~g}, 1.92 \mathrm{mmol}, 1.0$ equiv. $)$ in dry $\mathrm{CH}_{2} \mathrm{Cl}_{2}(5 \mathrm{~mL})$ at ambient temperature, was added $\mathrm{Et}_{3} \mathrm{~N}(0.54 \mathrm{~mL}, 3.84 \mathrm{mmol}, 2.0$ equiv. $)$ dropwise. This solution was left stirring for $5 \mathrm{~min}$ then cooled to $0{ }^{\circ} \mathrm{C}$. Then methanesulfonyl chloride $(0.45 \mathrm{~mL}, 5.76 \mathrm{mmol}, 3.0$ equiv. $)$ was added dropwise and the reaction was left at $0{ }^{\circ} \mathrm{C}$ for $10 \mathrm{~min}$ then warmed to ambient temperature and left overnight. The reaction mixture turned colourless to yellow. Then, brine $(10 \mathrm{~mL})$ was added dropwise and the volatiles concentrated in vacuo to afford a yellow liquid. This was poured over EtOAc $(50 \mathrm{~mL})$ and sat. aq. $\mathrm{NaHCO}_{3}(50 \mathrm{~mL})$ was added. The organic layer was separated and the aqueous layer extracted with EtOAc $(2 \times 50 \mathrm{~mL})$. The organic layers were combined and washed with brine $(1 \times 50 \mathrm{~mL})$, dried over $\mathrm{MgSO}_{4}$, filtered and concentrated in vacuo to afford a crude yellow oil. This was then purified by column chromatography on silica (hexane/EtOAc 95:5) to afford the compound pre-13a as a colourless oil. Yield: $0.497 \mathrm{~g},(90 \%) ;[\alpha]_{D}^{26}=+79^{\circ}\left(c=0.8, \mathrm{CHCl}_{3}\right) ;{ }^{1} \mathrm{H}-\mathrm{NMR}\left(400 \mathrm{MHz}, \mathrm{CDCl}_{3}\right) \delta 5.60-5.50(\mathrm{~m}, 2 \mathrm{H})$, 4.21-4.12 (m, 2H), $2.94(\mathrm{~s}, 3 \mathrm{H}), 2.25-2.11(\mathrm{~m}, 1 \mathrm{H}), 2.11-1.99(\mathrm{~m}, 2 \mathrm{H}), 1.98-1.83(\mathrm{~m}, 2 \mathrm{H}), 1.83-1.76(\mathrm{~m}, 1 \mathrm{H})$, 1.71-1.55 (m, 3H), 1.40-1.30 (m, 2H), 1.28-1.10 (m, 5H), $0.82(\mathrm{t}, J=7.0 \mathrm{~Hz}, 3 \mathrm{H}) ;{ }^{13} \mathrm{C}-\mathrm{NMR}(100 \mathrm{MHz}$, $\mathrm{CDCl}_{3}$ ) $\delta 125.3,124.4,70.3,50.0,38.1,37.4,36.6,36.4,35.4,35.3,30.7,26.4,22.8,21.4,14.1$; IR (neat, $\mathrm{cm}^{-1}$ ) $3020(\mathrm{w}), 2925(\mathrm{~m}), 1354(\mathrm{~s})$; HRMS (EI+): Exact mass calculated for $\mathrm{C}_{15} \mathrm{H}_{26} \mathrm{O}_{3} \mathrm{~S}_{2}[M]^{+}:$286.1603, found 286.1627; TLC (hexane/EtOAc 4:1, $\mathrm{KMnO}_{4}$ stain): $\mathrm{R}_{\mathrm{f}}=0.50$.

\subsubsection{Synthesis of Nitrile pre-13b}

To a stirring solution of mesylate pre-13a $(0.497 \mathrm{~g}, 1.74 \mathrm{mmol}, 1.0$ equiv. $)$ in dry DMSO $(30 \mathrm{~mL})$ was added solid $\mathrm{KCN}(0.675 \mathrm{~g}, 10.4 \mathrm{mmol}, 6.0$ equiv. $)$ in one portion. The reaction mixture was then heated to $70{ }^{\circ} \mathrm{C}$ for $2 \mathrm{~h}$. The reaction mixture changed from colourless to yellow. Then, the reaction was cooled to r.t. and $\mathrm{H}_{2} \mathrm{O}(5 \mathrm{~mL})$ was added dropwise. The reaction mixture turned from yellow to colourless. This was then poured over EtOAc $(20 \mathrm{~mL})$ and the organic layer separated. The aqueous layer was extracted with EtOAc $(2 \times 20 \mathrm{~mL})$ and the organic layers combined. They were then washed with brine $(1 \times 50 \mathrm{~mL})$, dried over $\mathrm{MgSO}_{4}$, filtered and concentrated in vacuo to afford a crude brown oil. This was then purified by column chromatography on silica (hexane/EtOAc 98:2) to give the compound pre-13b as a colourless oil. Yield: $0.325,(86 \%) ;[\alpha]_{D}^{26}=+111^{\circ}\left(c=0.8, \mathrm{CHCl}_{3}\right) ;{ }^{1} \mathrm{H}-\mathrm{NMR}(400 \mathrm{MHz}$, $\left.\mathrm{CDCl}_{3}\right) \delta 5.82-5.47(\mathrm{~m}, 2 \mathrm{H}), 2.42-2.28(\mathrm{~m}, 2 \mathrm{H}), 2.18-2.14(\mathrm{~m}, 2 \mathrm{H}), 2.04-1.85(\mathrm{~m}, 3 \mathrm{H}), 1.74-1.65(\mathrm{~m}, 3 \mathrm{H})$, 1.51-1.35 (m, 2H), 1.33-1.19 (m, 5H), $0.89(\mathrm{t}, J=7.0 \mathrm{~Hz}, 3 \mathrm{H}){ }^{13} \mathrm{C}-\mathrm{NMR}\left(100 \mathrm{MHz}, \mathrm{CDCl}_{3}\right) \delta 125.4$, 124.2, 119.6, 47.3, 41.4, 37.9, 35.8, 35.7, 35.1, 30.6, 26.5, 22.8, 21.5, 17.7, 14.1; IR (neat, $\mathrm{cm}^{-1}$ ) $3026(\mathrm{w})$, 2919 (s), 2248 (w), 1465 (w) $1436(w)$; HRMS (EI+): Exact mass calculated for $\mathrm{C}_{15} \mathrm{H}_{23} \mathrm{~N}[M]^{+}:$217.1830, found 217.1845; TLC (hexane/EtOAc 4:1, $\mathrm{KMnO}_{4}$ stain): $\mathrm{R}_{\mathrm{f}}=0.80$.

\subsubsection{Synthesis of Aldehyde 13}

A stirring solution of nitrile pre-13b $(0.322 \mathrm{~g}, 1.48 \mathrm{mmol}, 1.0$ equiv.) in hexane $(10 \mathrm{~mL})$ was cooled to $-78^{\circ} \mathrm{C}$. Then DIBAL-H (1M in hexane) $(2.20 \mathrm{~mL}, 2.22 \mathrm{mmol}, 1.5$ equiv.) was added dropwise over $5 \mathrm{~min}$ and the reaction left to stir for $20 \mathrm{~min}$. Then sat. aq. Rochelle salt $(5 \mathrm{~mL})$ was added dropwise to the reaction mixture and then left to warm to ambient temperature. The resulting cloudy suspension was poured over EtOAc $(20 \mathrm{~mL})$ and sat. aq. Rochelle salt $(20 \mathrm{~mL})$. The organic layer was separated and the aqueous phase extracted with EtOAc $(2 \times 20 \mathrm{~mL})$. The organic phases were combined and washed with brine $(1 \times 50 \mathrm{~mL})$, dried over $\mathrm{MgSO}_{4}$, filtered and concentrated in vacuo to afford a crude cloudy oil. This was then purified by column chromatography on silica (hexane/EtOAc, 95:5) to afford the compound $\mathbf{1 3}$ as a colourless oil. Yield: $0.253 \mathrm{mg},(78 \%) ;[\alpha]_{D}^{26}=+101^{\circ}\left(c=0.8, \mathrm{CHCl}_{3}\right) ;{ }^{1} \mathrm{H}-\mathrm{NMR}\left(400 \mathrm{MHz}, \mathrm{CDCl}_{3}\right) \delta$ $9.79(\mathrm{t}, J=2.3 \mathrm{~Hz}, 1 \mathrm{H}), 5.68-5.51(\mathrm{~m}, 2 \mathrm{H}), 2.49-2.44(\mathrm{~m}, 2 \mathrm{H}), 2.35-2.23(\mathrm{~m}, 1 \mathrm{H}), 2.22-2.12(\mathrm{~m}, 1 \mathrm{H}), 2.10-1.98$ $(\mathrm{m}, 2 \mathrm{H}), 1.92-1.78(\mathrm{~m}, 2 \mathrm{H}), 1.74-1.60(\mathrm{~m}, 3 \mathrm{H}), 1.47-1.35(\mathrm{~m}, 2 \mathrm{H}), 1.35-1.15(\mathrm{~m}, 5 \mathrm{H}), 0.88(\mathrm{t}, J=7.0 \mathrm{~Hz}, 3 \mathrm{H})$; ${ }^{13} \mathrm{C}-\mathrm{NMR}\left(100 \mathrm{MHz}, \mathrm{CDCl}_{3}\right) \delta$ 202.9, 125.3, 124.7, 45.2, 44.7, 41.4, 37.5, 35.7, 35.6, 34.9, 30.8, 26.7, 22.9, 
22.1, 14.1; IR (neat, $\mathrm{cm}^{-1}$ ) 3020 (w), 2919 (m), 2712 (w), 1723 (s); HRMS (EI+): Exact mass calculated for $\mathrm{C}_{15} \mathrm{H}_{24} \mathrm{O}[M]^{+}:$220.1827, found 220.1824; TLC (hexane/EtOAc 4:1, $\mathrm{KMnO}_{4}$ stain): $\mathrm{R}_{\mathrm{f}}=0.80$.

\subsection{Synthesis of Alkyne $\mathbf{1 4}$}

To a stirring solution of aldehyde $13(0.253 \mathrm{~g}, 1.15 \mathrm{mmol}, 1.0$ equiv. $)$ in dry $\mathrm{MeOH}(6 \mathrm{~mL})$ at $0{ }^{\circ} \mathrm{C}$ was added solid $\mathrm{K}_{2} \mathrm{CO}_{3}(0.381 \mathrm{mg}, 2.76 \mathrm{mmol}$, 2.4 equiv.) in one portion and Ohira-Bestmann reagent $(10 \% w / w$ in $\mathrm{MeCN})(3.9 \mathrm{~mL}, 3.32 \mathrm{~g}, 1.73 \mathrm{mmol}, 1.5$ equiv.). The suspension was then warmed to ambient temperature and left stirring $1 \mathrm{~h}$. After analysis by TLC the mixture was treated with sat. aq. $\mathrm{NaHCO}_{3}(20 \mathrm{~mL})$, and the resulting mixture poured over $\mathrm{CH}_{2} \mathrm{Cl}_{2}(20 \mathrm{~mL})$. The organic phase was separated and the aqueous phase was washed with $\mathrm{CH}_{2} \mathrm{Cl}_{2}(3 \times 10 \mathrm{~mL})$. The organic phases were then combined, dried over $\mathrm{Na}_{2} \mathrm{SO}_{4}$, filtered and concentrated in vacuo to afford a crude oil. This was purified by column chromatography on silica (hexane/EtOAc, 95:5) to afford the compound 14 as a colourless oil. Yield: $0.193 \mathrm{~g},(78 \%) ;[\alpha]_{D}^{26}=+119^{\circ}\left(c=0.8, \mathrm{CHCl}_{3}\right) ;{ }^{1} \mathrm{H}-\mathrm{NMR}(400 \mathrm{MHz}$, $\left.\mathrm{CDCl}_{3}\right) \delta 5.72-5.58(\mathrm{~m}, 2 \mathrm{H}), 2.35-2.24(\mathrm{~m}, 2 \mathrm{H}), 2.18-2.09(\mathrm{~m}, 3 \mathrm{H}), 2.07-1.98(\mathrm{~m}, 1 \mathrm{H}), 1.91(\mathrm{t}, J=2.7 \mathrm{~Hz}$, $1 \mathrm{H}), 1.89-1.83(\mathrm{~m}, 1 \mathrm{H}), 1.83-1.75(\mathrm{~m}, 1 \mathrm{H}), 1.75-1.55(\mathrm{~m}, 3 \mathrm{H}), 1.55-1.45(\mathrm{~m}, 1 \mathrm{H}), 1.45-1.36(\mathrm{~m}, 1 \mathrm{H})$, 1.36-1.13 (m, 5H), $0.89(\mathrm{t}, J=7.1 \mathrm{~Hz}, 3 \mathrm{H}) ;{ }^{13} \mathrm{C}-\mathrm{NMR}\left(100 \mathrm{MHz}, \mathrm{CDCl}_{3}\right) \delta ; 125.2,125.0,84.4,67.9$, 50.2, 41.2, 37.7, 36.1, 35.9, 35.2, 30.8, 26.8, 22.9, 21.4, 18.9, 14.1; IR (neat, $\mathrm{cm}^{-1}$ ) $3311(\mathrm{~m}), 3020(\mathrm{w})$, 2919 (s), $1432(\mathrm{~m})$; HRMS (EI+): Exact mass calculated for $\mathrm{C}_{16} \mathrm{H}_{24}[M]^{+}:$216.1878, found 216.1867; TLC (hexane, $\mathrm{KMnO}_{4}$ stain and anisaldehyde dip): $\mathrm{R}_{\mathrm{f}}=0.25$.

\subsection{Synthesis of exo-Mucosin $\mathbf{1}^{*}$}

\subsubsection{Synthesis of Ethyl Ester 15}

To a stirring solution of $\mathrm{Cp}_{2} \mathrm{ZrCl}_{2}(0.400 \mathrm{~g}, 1.37 \mathrm{mmol}, 2.0$ equiv. $)$ in dry $\mathrm{THF}(8 \mathrm{~mL})$ at $0{ }^{\circ} \mathrm{C}$ was added DIBAL-H (1M in hexane) (1.37 $\mathrm{mL}, 1.37 \mathrm{mmol}, 2.0$ equiv.) via dropwise addition. The resulting homogenous mixture was then protected from light and stirred at $0{ }^{\circ} \mathrm{C}$ for $1 \mathrm{~h}$ after which time a colourless heterogeneous mixture formed. Then alkyne $14(0.148 \mathrm{~g}, 0.684 \mathrm{mmol}, 1.0$ equiv. $)$ dissolved in dry THF $(4 \mathrm{~mL})$ was added dropwise to the reaction mixture at $0{ }^{\circ} \mathrm{C}$. After $1 \mathrm{~h}$ at $0{ }^{\circ} \mathrm{C}$ iodine $(0.260 \mathrm{~g}$, $1.02 \mathrm{mmol}, 1.5$ equiv.) was added in one portion to the homogeneous yellow reaction mixture. The reaction mixture was then warmed to ambient temperature and stirred for $1 \mathrm{~h}$. To the preformed vinyl iodide was successively added 4-ethoxy-4-oxobutylzinc bromide solution (0.5M in THF) (2.7 mL, $1.37 \mathrm{mmol}$, 2.0 equiv.) dropwise and $\left(\mathrm{Ph}_{3} \mathrm{P}\right)_{4} \mathrm{Pd}(0.079 \mathrm{~g}, 0.068 \mathrm{mmol}, 0.1$ equiv. $)$ in one portion. The resulting light brown mixture was stirred at ambient temperature for $1 \mathrm{~h}$ and monitored by TLC. Once the reaction had gone to completion $1 \mathrm{M} \mathrm{HCl}(10 \mathrm{~mL})$ was added dropwise and the reaction poured over $\mathrm{Et}_{2} \mathrm{O}$ $(15 \mathrm{~mL})$. The aqueous phase was extracted with $\mathrm{Et}_{2} \mathrm{O}(3 \times 50 \mathrm{~mL})$ and the organic phases combined, dried over $\mathrm{MgSO}_{4}$, filtered and concentrated in vacuo to form a crude brown oily mixture. This oily mixture was purified by column chromatography on silica (hexane/EtOAc, 95:5) to afford the compound 15 as a colourless oil. Yield: $0.196 \mathrm{~g},(86 \%) ;[\alpha]_{D}^{26}=+67^{\circ}\left(c=0.8, \mathrm{CHCl}_{3}\right) ;{ }^{1} \mathrm{H}-\mathrm{NMR}(400 \mathrm{MHz}$, $\left.\mathrm{CDCl}_{3}\right) \delta 5.69-5.56(\mathrm{~m}, 2 \mathrm{H}), 5.48-5.33(\mathrm{~m}, 2 \mathrm{H}), 4.12(\mathrm{q}, J=7.1 \mathrm{~Hz}, 2 \mathrm{H}), 2.31-2.21$ (appt, $J=7.5 \mathrm{~Hz}$, $3 \mathrm{H}), 2.16-1.82(\mathrm{~m}, 8 \mathrm{H}), 1.75-1.50(\mathrm{~m}, 6 \mathrm{H}), 1.48-1.41(\mathrm{~m}, 1 \mathrm{H}), 1.39-1.22(\mathrm{~m}, 9 \mathrm{H}), 0.88(\mathrm{t}, J=7.1 \mathrm{~Hz}, 3 \mathrm{H})$; ${ }^{13} \mathrm{C}-\mathrm{NMR}\left(100 \mathrm{MHz}, \mathrm{CDCl}_{3}\right) \delta 173.8,131.2,129.1,125.3,125.1,60.2,51.6,41.3,37.3,36.2,35.6,35.5$, 33.7, 33.0, 31.9 31.0, 26.9, 24.8, 23.0, 21.7, 14.2, 14.1; IR (neat, $\mathrm{cm}^{-1}$ ) $3020(\mathrm{w}), 2925$ (m), 1734 (s); HRMS (EI+): Exact mass calculated for $\mathrm{C}_{22} \mathrm{H}_{36} \mathrm{O}_{2}[M]^{+}: 332.2715$, found 332.2709; TLC (hexane/EtOAc 95:5, $\mathrm{KMnO}_{4}$ stain): $\mathrm{R}_{\mathrm{f}}=0.65$.

\subsubsection{Synthesis of exo-Mucosin $\mathbf{1}^{*}$}

To a stirring solution of ethyl ester 15 ( $0.177 \mathrm{~g}, 0.533 \mathrm{mmol}, 1.0$ equiv.) in THF $/ \mathrm{MeOH} / \mathrm{H}_{2} \mathrm{O}(2: 2: 1)$ $(5 \mathrm{~mL})$ at ambient temperature was added lithium hydroxide monohydrate $(0.783 \mathrm{mg}, 18.7 \mathrm{mmol}$, 35.0 equiv.) in one portion. The reaction mixture was left stirring and monitored by TLC. Left overnight, the reaction had gone to completion and was acidified to $\mathrm{pH} 2$ by $1 \mathrm{M} \mathrm{HCl}(5 \mathrm{~mL})$. The reaction mixture 
was then poured over EtOAc $(5 \mathrm{~mL})$ and the aqueous phase extracted with EtOAc $(3 \times 5 \mathrm{~mL})$. The organic phases were combined and washed with brine $(1 \times 20 \mathrm{~mL})$, dried over $\mathrm{MgSO}_{4}$, filtered and concentrated in vacuo to provide a colourless oil. This was purified by column chromatography on silica (hexane/EtOAc, 3:2) to afford the compound $1^{*}$ as a colourless oil. Yield: $0.154 \mathrm{~g}$, (95\%); $[\alpha]_{D}^{26}=+77^{\circ}\left(c=0.8\right.$, hexane); ${ }^{1} \mathrm{H}-\mathrm{NMR}\left(400 \mathrm{MHz}, \mathrm{CDCl}_{3}\right) \delta 11.63(\mathrm{br}, 1 \mathrm{H}), 5.67-5.56(\mathrm{~m}, 2 \mathrm{H})$, 5.50-5.34 (m, 2H), $2.34(\mathrm{t}, J=7.5 \mathrm{~Hz}, 2 \mathrm{H}), 2.33-2.22(\mathrm{~m}, 1 \mathrm{H}), 2.15-2.12(\mathrm{~m}, 8 \mathrm{H}), 1.77-1.49(\mathrm{~m}, 6 \mathrm{H})$, 1.48-1.40 (m,1H), 1.40-1.08 (m, 6H), $0.88(\mathrm{t}, J=6.7 \mathrm{~Hz}, 3 \mathrm{H}) ;{ }^{13} \mathrm{C}-\mathrm{NMR}\left(100 \mathrm{MHz}, \mathrm{CDCl}_{3}\right) \delta 180.3$, 131.4, 128.9, 125.3, 125.1, 51.6, 41.3, 37.3, 36.2, 35.6, 35.5, 33.4, 33.0, 31.8, 31.0, 26.9, 24.5, 23.0, 21.7, 14.2; IR (neat, $\mathrm{cm}^{-1}$ ) $3020(\mathrm{w}), 2925(\mathrm{~m}), 1712(\mathrm{~s})$; HRMS (EI+): Exact mass calculated for $\mathrm{C}_{20} \mathrm{H}_{32} \mathrm{O}_{2}[M]^{+}$: 304.2402, found 304.2400; TLC (hexane/EtOAc 3:2, $\mathrm{KMnO}_{4}$ stain): $\mathrm{R}_{\mathrm{f}}=0.40$.

\subsubsection{Synthesis of Methyl Ester 2*}

To a stirring solution of exo-mucosin $\mathbf{1}^{*}(0.023 \mathrm{~g}, 0.076 \mathrm{mmol}, 1.0$ equiv.) in toluene/MeOH (3:2) $(5 \mathrm{~mL})$ at ambient temperature was added TMS diazomethane solution ( $2 \mathrm{M}$ in hexane) $(0.06 \mathrm{~mL}$, $0.113 \mathrm{mmol}, 1.5$ equiv.) dropwise over $2 \mathrm{~min}$. The reaction mixture bubbled and turned transparent yellow. The reaction was monitored by TLC and after $1 \mathrm{~h}$ had gone to completion. The reaction mixture was then concentrated in vacuo and directly purified by column chromatography on silica (hexane/EtOAc, 95:5) to afford the compound $2^{*}$ as a colourless oil. Yield: $23 \mathrm{mg},(96 \%) ;[\alpha]_{D}^{26}=+64^{\circ}$ $\left(c=0.8\right.$, hexane); ${ }^{1} \mathrm{H}-\mathrm{NMR}\left(400 \mathrm{MHz}, \mathrm{CDCl}_{3}\right) \delta 5.69-5.56(\mathrm{~m}, 2 \mathrm{H}), 5.49-5.32(\mathrm{~m}, 2 \mathrm{H}), 3.66(\mathrm{~s}, 3 \mathrm{H})$, $2.29(\mathrm{t}, J=7.5 \mathrm{~Hz}, 2 \mathrm{H}), 2.26-2.21(\mathrm{~m}, 1 \mathrm{H}), 2.13-1.82(\mathrm{~m}, 8 \mathrm{H}), 1.75-1.63(\mathrm{~m}, 3 \mathrm{H}), 1.63-1.50(\mathrm{~m}, 3 \mathrm{H})$, 1.40-1.08 (m, 7H), $0.88(\mathrm{t}, J=7.1 \mathrm{~Hz}, 3 \mathrm{H}) ;{ }^{13} \mathrm{C}-\mathrm{NMR}\left(100 \mathrm{MHz}, \mathrm{CDCl}_{3}\right) \delta ; 174.2,131.2,129.0$, 125.3, 125.1, 51.6, 51.4, 41.3, 37.2, 36.2, 35.5, 35.4, 33.4, 33.0, 31.9, 31.0, 26.9, 24.7, 23.0, 21.7, 14.1; IR (neat, $\mathrm{cm}^{-1}$ ) 3020 (w), 2925 (s), 1745 (s); HRMS (EI+): Exact mass calculated for $\mathrm{C}_{21} \mathrm{H}_{34} \mathrm{O}_{2}[M]^{+}$: 318.2559, found 318.2552; TLC (hexane/EtOAc 95:5, $\mathrm{KMnO}_{4}$ stain): $\mathrm{R}_{\mathrm{f}}=0.65$.

\section{Conclusions}

To recapitulate our findings, we have investigated the anti-diastereomer $2 *$ of the proposed structure 2. Through the execution of 13 discrete linear steps, the target molecule was obtained in an overall yield of $11 \%$ and in multi-milligram quantities. By incorporating a Michael acceptor motif, we have revealed an innate topological bias of the cis-fused bicyclo[4.3.0]non-3-ene system. Combined with our previously developed three step one-pot alkyne iteration, we have shown that exo-mucosin $\mathbf{1}^{*}$ is not identical to the natural product. In terms of the synthetic sequence detailed by Whitby and co-workers [37], our findings must necessarily have some mechanistic implications. Thus, we conclude that zirconium induced co-cyclisation did not deliver any of the two anti-diastereomers, $\mathbf{1}$ and $\mathbf{1}^{*}$ respectively, by the published procedure. Achieving a synthesis that establishes the true structure of mucosin will therefore also provide mechanistic insight into this matter. Based on the present work and what has previously been published [36,37], the fusion geometry of the hydrindane core embedded within mucosin is most likely trans.

Supplementary Materials: Electronic supplementary information is available online with full experimental procedures and characterisation data for all new compounds; crystal data and refinement details are included to give evidence of the relative stereochemistry of the late stage intermediate 12 .

Acknowledgments: The authors are much indebted to Dag Ekeberg for the performance of mass spectrometric analysis. Scholarships for S.G.A. and H.G.-S. from the Department of Chemistry, the Norwegian University of Life Sciences, as well as funding from the Research Council of Norway for a research scholarship to J.M.J.N. and grants to Y.H.S. (NFR 209335 and NFR 244351) are gratefully acknowledged.

Author Contributions: S.G.A. and H.G.-S. contributed equally to the practical work. C.H.G. performed the crystallographic acquisition and analysis. T.V.H. and Y.H.S. supervised and oversaw the project. Y.H.S. prepared the crystals for X-ray analysis. J.M.J.N. executed the diastereoselective addition and the alkyne iteration, developed the key stereopermutation concept and wrote the manuscript. All authors read and approved the final manuscript.

Conflicts of Interest: The authors declare no conflict of interest. 


\section{References and Notes}

1. Samuelsson, B. Role of basic science in the development of new medicines: Examples from the eicosanoid field. J. Biol. Chem. 2012, 287, 10070-10080. [CrossRef] [PubMed]

2. Flower, R.J. Prostaglandins, bioassay and inflammation. Br. J. Pharmacol. 2006, 147, S182-S192. [CrossRef] [PubMed]

3. Serhan, C.N. Pro-resolving lipid mediators are leads for resolution physiology. Nature 2014, 510, 92-101. [CrossRef] [PubMed]

4. Basil, M.C.; Levy, B.D. Specialized pro-resolving mediators: Endogenous regulators of infection and inflammation. Nat. Rev. Immunol. 2016, 16, 51-67. [CrossRef] [PubMed]

5. Goldblatt, M.W. A Depressor substance in seminal fluid. Chem. Ind. 1933, 52, 1056-1057.

6. Von Euler, U.S. Über die spezifische blutdrucksenkende substanz des menschlichen prostata- und samenblasensekretes. Klin. Wochenschr. 1935, 14, 1182-1183. [CrossRef]

7. Bergström, S.; Sjövall, J. The isolation of prostaglandin. Acta Chem. Scand. 1957, 11, 1086. [CrossRef]

8. Bergström, S.; Ryhage, R.; Samuelsson, B.; Sjövall, J. Prostaglandins and related factors: 15. The structures of prostaglandin $\mathrm{E}_{1}, \mathrm{~F}_{1 \beta}$ and $\mathrm{F}_{1 \beta}$. J. Biol. Chem. 1963, 238, 3555-3564.

9. Hamberg, M.; Samuelsson, B. On the mechanism of the biosynthesis of prostaglandins $E_{1}$ and $F_{1 \beta}$. J. Biol. Chem. 1967, 242, 5336-5343. [PubMed]

10. Corey, E.J.; Weinshenker, N.M.; Schaaf, T.K.; Huber, W. Stereo-controlled synthesis of prostaglandins $F_{2 \beta}$ and $\mathrm{E}_{2}(\mathrm{dl})$. . J. Am. Chem. Soc. 1969, 91, 5675-5677. [CrossRef] [PubMed]

11. Smith, W.L.; Lands, W.E.M. Stimulation and blockade of prostaglandin biosynthesis. J. Biol. Chem. 1971, 246, 6700-6702. [PubMed]

12. Corey, E.J.; Ensley, H.E. Preparation of an optically active prostaglandin intermediate via asymmetric induction. J. Am. Chem. Soc. 1975, 97, 6908-6909. [CrossRef] [PubMed]

13. Dewitt, D.L.; El-Harith, E.A.; Kraemer, S.A.; Andrews, M.J.; Yao, E.F.; Armstrong, R.L.; Smith, W.L. The aspirin and heme-binding sites of ovine and murine prostaglandin endoperoxide synthases. J. Biol. Chem. 1990, 265, 5192-5198. [PubMed]

14. Noverr, M.C.; Erb-Downward, J.R.; Huffnagle, G.B. Production of eicosanoids and other oxylipins by pathogenic eukaryotic microbes. Clin. Microbiol. Rev. 2003, 16, 517-533. [CrossRef] [PubMed]

15. Ricciotti, E.; FitzGerald, G.A. Prostaglandins and inflammation. Arterioscler. Thromb. Vasc. Biol. 2011, 31, 986-1000. [CrossRef] [PubMed]

16. Serhan, C.N. The resolution of inflammation: The devil in the flask and in the details. FASEB J. 2011, 25, 1441-1448. [CrossRef] [PubMed]

17. Wagner, K.; Vito, S.; Inceoglu, B.; Hammock, B.D. The role of long chain fatty acids and their epoxide metabolites in nociceptive signaling. Prostaglandins Other Lipid Mediat. 2014, 113-115, 2-12. [CrossRef] [PubMed]

18. Aursnes, M.; Tungen, J.E.; Vik, A.; Colas, R.; Cheng, C.-Y.C.; Dalli, J.; Serhan, C.N.; Hansen, T.V. Total synthesis of the lipid mediator PD1 $1_{\mathrm{n}-3}$ DPA: Configurational assignments and anti-inflammatory and pro-resolving actions. J. Nat. Prod. 2014, 77, 910-916. [CrossRef] [PubMed]

19. Tungen, J.E.; Aursnes, M.; Vik, A.; Ramon, S.; Colas, R.A.; Dalli, J.; Serhan, C.N.; Hansen, T.V. Synthesis and anti-inflammatory and pro-resolving activities of 22-OH-PD1, a monohydroxylated metabolite of protectin D1. J. Nat. Prod. 2014, 77, 2241-2247. [CrossRef] [PubMed]

20. Serhan, C.N.; Chiang, N.; Dalli, J. The resolution code of acute inflammation: Novel pro-resolving lipid mediators in resolution. Semin. Immunol. 2015, 27, 200-215. [CrossRef] [PubMed]

21. Primdahl, K.G.; Aursnes, M.; Walker, M.E.; Colas, R.A.; Serhan, C.N.; Dalli, J.; Hansen, T.V.; Vik, A. Synthesis of 13(R)-hydroxy-7Z,10Z,13R,14E,16Z,19Z docosapentaenoic acid (13R-HDPA) and its biosynthetic conversion to the 13-Series Resolvins. J. Nat. Prod. 2016, 79, 2693-2702. [CrossRef] [PubMed]

22. Ramon, S.; Dalli, J.; Sanger, J.M.; Winkler, J.W.; Aursnes, M.; Tungen, J.E.; Hansen, T.V.; Serhan, C.N. The protectin PCTR1 is produced by human M2 macrophages and enhances resolution of infectious inflammation. Am. J. Pathol. 2016, 186, 962-973. [CrossRef] [PubMed]

23. Serhan, C.N. Treating inflammation and infection in the 21st century: New hints from decoding resolution mediators and mechanisms. FASEB J. 2017, 31, 1273-1288. [CrossRef] [PubMed] 
24. Dias, D.A.; Urban, S.; Roessner, U. A historical overview of natural products in drug discovery. Metabolites 2012, 2, 303-306. [CrossRef] [PubMed]

25. Gerwick, W.H.; Moore, B.S. Lessons from the past and charting the future of marine natural products drug discovery and chemical biology. Chem. Biol. 2012, 19, 85-98. [CrossRef] [PubMed]

26. McGovern, P.E.; Michel, R.H. Royal purple dye: Tracing the chemical origins of the industry. Anal. Chem. 1985, 57, 1514A-1522A.

27. Cooksey, C.J. Tyrian purple: 6,6'-Dibromoindigo and related compounds. Molecules 2001, 6, 736-769. [CrossRef]

28. Leal, M.C.; Puga, J.; Serôdio, J.; Gomes, N.C.M.; Calado, R. Trends in the discovery of new marine natural products from invertebrates over the last two decades-Where and what are we bioprospecting? PLoS ONE 2012, 7, e30580. [CrossRef] [PubMed]

29. Montaser, R.; Luesch, H. Marine natural products: A new wave of drugs? Future Med. Chem. 2011, 3, 1475-1489. [CrossRef] [PubMed]

30. Blunt, J.W.; Copp, B.R.; Keyzers, R.A.; Munro, M.H.G.; Prinsep, M.R. Marine natural products. Nat. Prod. Rep. 2016, 33, 382-431. [CrossRef] [PubMed]

31. Blunt, J.W.; Copp, B.R.; Keyzers, R.A.; Munro, M.H.G.; Prinsep, M.R. Marine natural products. Nat. Prod. Rep. 2015, 32, 116-211. [CrossRef] [PubMed]

32. Blunt, J.W.; Copp, B.R.; Keyzers, R.A.; Munro, M.H.G.; Prinsep, M.R. Marine natural products. Nat. Prod. Rep. 2014, 31, 160-258. [CrossRef] [PubMed]

33. Blunt, J.W.; Copp, B.R.; Munro, M.H.G.; Northcote, P.T.; Prinsep, M.R. Marine natural products. Nat. Prod. Rep. 2005, 22, 15-61. [CrossRef] [PubMed]

34. Faulkner, D.J. Marine natural products. Nat. Prod. Rep. 2001, 18, 1-49. [CrossRef] [PubMed]

35. Casapullo, A.; Scognamiglio, G.; Cimino, G. Mucosin: A new bicyclic eicosanoid from the Mediterranean sponge Reniera mucosa. Tetrahedron Lett. 1997, 38, 3643-3646. [CrossRef]

36. Gallantree-Smith, H.C.; Antonsen, S.G.; Görbitz, C.H.; Hansen, T.V.; Nolsøe, J.M.J.; Stenstrøm, Y.H. Total synthesis based on the originally claimed structure of mucosin. Org. Biomol. Chem. 2016, 14, 8433-8437. [CrossRef] [PubMed]

37. Henderson, A.R.; Stec, J.; Owen, D.R.; Whitby, R.J. The first total synthesis of (+)-mucosin. Chem. Commun. 2012, 48, 3409-3411. [CrossRef] [PubMed]

38. Bunn, B.J.; Simpkins, N.S.; Spavold, Z.; Crimmin, M.J. The effect of added salts on enantioselective transformations of cyclic ketones by chiral lithium amide bases. J. Chem. Soc. Perkin Trans. 1 1993, 24, 3113-3116. [CrossRef]

39. Bunn, B.J.; Cox, P.J.; Simpkins, N.S. Enantioselective deprotonation of 8-oxabicyclo[3.2.1]octan-3-one systems using homochiral lithium amide bases. Tetrahedron 1993, 49, 207-218. [CrossRef]

40. Rodeschini, V.; Simpkins, N.S.; Wilson, C. Kinetic resolution in a bridgehead lithiation mediated by a chiral Bis-lithium amide: Assignment of the absolute configuration of clusianone. J. Org. Chem. 2007, 72, 4265-4267. [CrossRef] [PubMed]

41. Normant, J.F. Organocopper(I) compounds and organocuprates in synthesis. Synthesis 1972, 2, 63-80. [CrossRef]

42. Posner, G.H. Conjugate addition reactions of organocopper reagents. Org. Reac. 1972, 19, 1-113.

43. Lipshutz, B.H. Applications of higher-order mixed organocuprates to organic synthesis. Synthesis 1987, 4, 325-341. [CrossRef]

44. Dambrin, V.; Villiéras, M.; Lebreton, J.; Toupet, L.; Amri, H.; Villiéras, J. Copper (I) mediated highly diastereoselective conjugate addition of Grignard reagents to functionalised 6-membered ring cycloalkenols. Synthesis of cyclohexanes derivatives substituted on three contiguous atoms. Tetrahedron Lett. 1999, 40, 871-874. [CrossRef]

45. Dambrin, V.; Villiéras, M.; Janvier, P.; Toupet, L.; Amri, H.; Lebreton, J.; Villiéras, J. Copper(I) mediated highly diastereoselective conjugate addition of Grignard reagents to functionalised cycloalkenols: A general and efficient route for the stereoselective synthesis of 5- and 6-membered ring trisubstituted cycloalkanols. Tetrahedron 2001, 57, 2155-2170. [CrossRef]

46. Harutyunyan, S.R.; López, F.; Browne, W.R.; Correa, A.; Peña, D.; Badorrey, R.; Meetsma, A.; Minnaard, A.J.; Feringa, B.L. On the mechanism of the copper-catalyzed enantioselective 1,4-addition of Grignard reagents to $\alpha, \beta$-unsaturated carbonyl compounds. J. Am. Chem. Soc. 2006, 128, 9103-9118. [CrossRef] [PubMed] 
47. Ohira, S. Methanolysis of dimethyl (1-diazo-2-oxopropyl) phosphonate: Generation of dimethyl (diazomethyl) phosphonate and reaction with carbonyl compounds. Synth. Commun. 1989, 19, 561-564. [CrossRef]

48. Müller, S.; Liepold, B.; Roth, G.J.; Bestmann, H.J. An improved one-pot procedure for the synthesis of alkynes from aldehydes. Synlett 1996, 6, 521-522. [CrossRef]

49. Habrant, D.; Rauhala, V.; Koskinen, A.M.P. Conversion of carbonyl compounds to alkynes: General overview and recent developments. Chem. Soc. Rev. 2010, 39, 2007-2017. [CrossRef] [PubMed]

50. Taber, D.F.; Bai, S.; Guo, P.-F. A convenient reagent for aldehyde to alkyne homologation. Tetrahedron Lett. 2008, 49, 6904-6906. [CrossRef] [PubMed]

51. Wilke, G.; Müller, H. Dialkylaluminiumhydride als sterisch spezifische reduktionsmittel für acetylene. Chem. Ber. 1956, 89, 444-447. [CrossRef]

52. Hart, D.W.; Blackburn, T.F.; Schwartz, J. Hydrozirconation. III. Stereospecific and regioselective functionalization of alkylacetylenes via vinylzirconium(IV) intermediates. J. Am. Chem. Soc. 1975, 97, 679-680. [CrossRef]

53. Brown, H.C.; Gupta, S.K. Hydroboration. XXXIX. 1,3,2-Benzodioxaborole (catecholborane) as a new hydroboration reagent for alkenes and alkynes. General synthesis of alkane- and alkeneboronic acids and esters via hydroboration. Directive effects in the hydroboration of alkenes and alkynes with catecholborane. J. Am. Chem. Soc. 1975, 97, 5249-5255.

54. Zhao, Y.; Snieckus, V. A Practical in situ generation of the Schwartz reagent. Reduction of Tertiary amides to aldehydes and hydrozirconation. Org. Lett. 2014, 16, 390-393. [CrossRef] [PubMed]

55. Yang, Z.; Zhong, M.; Ma, X.; Nijesh, K.; De, S.; Parameswaran, P.; Roesky, H.W. An aluminum dihydride working as a catalyst in hydroboration and dehydrocoupling. J. Am. Chem. Soc. 2016, 138, 2548-2551. [CrossRef] [PubMed]

56. Palei, B.A.; Gavrilenko, V.V.; Zakharkin, L.I. Comparative reactivity of alkyl, vinyl, and acetylene derivatives of aluminum. Russ. Chem. Bull. 1969, 18, 2590-2595. [CrossRef]

57. Diederich, F.; Stang, P. (Eds.) Metal-Catalyzed Cross Coupling Reactions; J. Wiley-VCH: Weinheim, Germany, 1998.

58. Huo, S. Highly efficient, general procedure for the preparation of alkylzinc reagents from unactivated alkyl bromides and chlorides. Org. Lett. 2003, 5, 423-425. [CrossRef] [PubMed]

59. Pohnert, G.; Boland, W. The oxylipin chemistry of attraction and defense in brown algae and diatoms. Nat. Prod. Rep. 2002, 19, 108-122. [PubMed]

60. Andreou, A.; Brodhun, F.; Feussner, I. Biosynthesis of oxylipins in non-mammals. Prog. Lipid Res. 2009, 48, 148-170. [CrossRef] [PubMed]

61. Barbosa, M.; Valentao, P.; Andrade, P.A. Biologically active oxylipins from enzymatic and nonenzymatic routes in macroalgae. Mar. Drugs 2016, 14, 23. [CrossRef] [PubMed]

62. Hoffman, R.; Woodward, R.B. The conservation of orbital symmetry. Acc. Chem. Res. 1968, 1, 17-22. [CrossRef]

63. Klas, K.; Tsukamoto, S.; Sherman, D.H.; Williams, R.M. Natural Diels-Alderases: Elusive and irresistible. J. Org. Chem. 2015, 80, 11672-11685. [CrossRef] [PubMed]

64. Jiang, Z.D.; Ketchum, S.O.; Gerwick, W.H. 5-Lipoxygenase-derived oxylipins from the red alga Rhodymenia pertusa. Phytochemistry 2000, 53, 129-133. [CrossRef]

65. Bernart, M.; Gerwick, W.H. Isolation of 12-(S)-hepe from the red marine alga Murrayella periclados and revision of structure of an acyclic icosanoid from Laurencia hybrida. Implications to the biosynthesis of the marine prostanoid hybridalactone. Tetrahedron Lett. 1988, 29, 2015-2018. [CrossRef]

66. Jiang, Z.D.; Gerwick, W.H. Novel oxylipins from the temperate red alga Polyneura latissima: Evidence for an arachidonate 9(S)-lipoxygenase. Lipids 1997, 32, 231-235. [CrossRef] [PubMed]

67. Lopez, A.; Gerwick, W.H. Two new icosapentaenoic acids from the temperate red seaweed Ptilota filicina J. Agardh. Lipids 1987, 22, 190-194. [CrossRef] [PubMed]

68. Solem, M.L.; Jiang, Z.D.; Gerwick, W.H. Three new and bioactive icosanoids from the temperate red marine alga Farlowia mollis. Lipids 1989, 24, 256-260. [CrossRef] [PubMed]

69. Hamberg, M.; Gerwick, W.H. Biosynthesis of vicinal dihydroxy fatty acids in the red alga Gracilariopsis lemaneiformis: Identification of a sodium-dependent 12-lipoxygenase and a hydroperoxide isomerase. Arch. Biochem. Biophys. 1993, 305, 115-122. [CrossRef] [PubMed] 
70. Gerwick, W.H.; Åsen, P.A.; Hamberg, M. Biosynthesis of 13R-hydroxyarachidonic acid, an unusual oxylipin from the red alga lithothamnion corallioides. Phytochemistry 1993, 34, 1029-1033. [CrossRef]

71. Burgess, J.R.; De la Rosa, R.I.; Jacobs, R.S.; Butler, A. A new eicosapentaenoic acid formed from arachidonic acid in the coralline red algae Bossiella orbigniana. Lipids 1991, 26, 162-165. [CrossRef]

72. Murakami, N.; Shirahashi, H.; Nagatsu, A.; Sakakibara, J. Two unsaturated 9R-hydroxy fatty acids from the cyanobacterium Anabaena flos-aquae $f$. flos-aquae. Lipids 1992, 27, 776-778. [CrossRef]

73. Moghaddam, M.F.; Gerwick, W.H.; Ballantine, D.L. Discovery of 12-(S)-hydroxy-5,8,10,14-icosatetraenoic acid [12-(S)-HETE] in the tropical red alga Platysiphonia miniata. Prostaglandines 1989, 37, 303-308. [CrossRef]

74. Weinberger, F.; Lion, U.; Delage, L.; Kloareg, B.; Potin, P.; Beltran, J.; Flores, V.; Faugeron, S.; Correa, J.; Pohnert, G. Up-regulation of lipoxygenase, phospholipase, and oxylipin-production in the induced chemical defense of the red alga Gracilaria chilensis against epiphytes. J. Chem. Ecol. 2011, 37, 677-686. [CrossRef] [PubMed]

75. Kuo, J.-M.; Hwang, A.; Yeh, D. Purification, substrate specificity, and products of a Ca ${ }^{2+}$-stimulating lipoxygenase from sea algae (Ulva lactuca). J. Agric. Food Chem. 1997, 45, 2055-2060. [CrossRef]

76. Mohamed, Y.M.A.; Hansen, T.V. Synthesis of methyl (5Z,8Z,10E,12E,14Z)-eicosapentaenoate. Tetrahedron Lett. 2011, 52, 1057-1059. [CrossRef]

77. Wise, M.L.; Hamberg, M.; Gerwick, W. Biosynthesis of conjugated triene-containing fatty acids by a novel isomerase from the red marine alga Ptilota filicina. Biochemistry 1994, 33, 15223-15232. [CrossRef] [PubMed]

78. Kennedy, J.; Auclair, K.; Kendrew, S.G.; Park, C.; Vederas, J.C.; Hutchinson, C.R. Modulation of polyketide synthase activity by accessory proteins during lovastatin biosynthesis. Science 1999, 284, 1368-1372. [CrossRef] [PubMed]

79. Auclair, K.; Sutherland, A.; Kennedy, J.; Witter, D.J.; Van den Heever, J.P.; Hutchinson, C.R.; Vederas, J.C. Lovastatin nonaketide synthase catalyzes an intramolecular Diels-Alder reaction of a substrate analogue. J. Am. Chem. Soc. 2000, 122, 11519-11520. [CrossRef]

80. Alt, S.; Wilkinson, B. Biosynthesis of the novel macrolide antibiotic anthracimycin. Chem. Biol. 2015, 10, 2468-2479. [CrossRef] [PubMed]

81. Oikawa, K.; Katayama, K.; Suzuki, Y.; Ichihara, A. Enzymatic activity catalysing exo-selective Diels-Alder reaction in solanapyrone biosynthesis. J. Chem. Soc. Chem. Commun. 1995, 13, 1321-1322. [CrossRef]

82. Kasahara, K.; Miyamaoto, T.; Fujimoto, T.; Oguri, H.; Tokiwano, T.; Oikawa, H.; Ebizuka, Y.; Fujii, I. Solanapyrone synthase, a possible Diels-Alderase and iterative Type I polyketide synthase encoded in a biosynthetic gene cluster from Alternaria solani. ChemBioChem 2010, 11, 1245-1252. [CrossRef] [PubMed]

83. Kim, H.J.; Ruszczycky, M.W.; Choi, S.-H.; Liu, Y.-N.; Liu, H.-W. Enzyme-catalysed [4+2] cycloaddition is a key step in the biosynthesis of spinosyn A. Nature 2011, 473, 109-112. [CrossRef] [PubMed]

84. Oikawa, H.; Yagi, K.; Watanabe, K.; Honma, M.; Ichihara, A. Biosynthesis of macrophomic acid: Plausible involvement of intermolecular Diels-Alder reaction. Chem. Commun. 1997, 1, 97-98. [CrossRef]

85. Ose, T.; Watanabe, K.; Mie, T.; Honma, M.; Watanabe, H.; Yao, M.; Oikawa, H.; Tanaka, I. Insight into a natural Diels-Alder reaction from the structure of macrophomate synthase. Nature 2003, 422, 185-189. [CrossRef] [PubMed]

86. Gerwick, W.H. Carbocyclic oxylipins of marine origin. Chem. Rev. 1993, 93, 1807-1823. [CrossRef]

87. Gerwick, W.H. Epoxy allylic carbocations as conceptual intermediates in the biogenesis of diverse marine oxylipins. Lipids 1996, 31, 1215-1231. [CrossRef] [PubMed]

88. Gerwick, W.H.; Singh, I.P. Structural diversity of marine oxylipins. In Lipid Biotechnology; Kuo, T.M., Gardner, H.W., Eds.; Marcel Dekker: New York, NY, USA, 2002; pp. 249-275.

89. Li, L.; Yu, P.; Tang, M.-C.; Zou, Y.; Gao, S.-S.; Hung, Y.-S.; Zhao, M.; Watanabe, K.; Houk, K.N.; Tang, Y. The catalytic mechanism of a natural Diels-Alderase revealed in molecular detail. J. Am. Chem. Soc. 2016, 138, 15837-15840. [CrossRef] [PubMed]

90. Kanoh, N.; Itoh, S.; Fujita, K.; Sakanishi, K.; Sugiyama, R.; Terajima, Y.; Iwabuchi, Y.; Nishimura, S.; Kakeya, H. Asymmetric total synthesis of heronamides A-C: Stereochemical Confirmation and impact of long-range stereochemical communication on the biological activity. Chem. Eur. J. 2016, 22, 8586-8595. [CrossRef] [PubMed]

91. Booth, T.J.; Alt, S.; Capon, R.J.; Wilkinson, B. Synchronous intramolecular cycloadditions of the polyene macrolactam polyketide heronamide C. Chem. Commun. 2016, 52, 6383-6386. [CrossRef] [PubMed] 
92. Yu, P.; Patel, A.; Houk, K.N. Transannular [6+4] and ambimodal cycloaddition in the biosynthesis of heronamide A. J. Am. Chem. Soc. 2015, 137, 13518-13523. [CrossRef] [PubMed]

93. Lin, C.-I.; McCarty, R.M.; Liu, H.-W. The enzymology of organic transformations: A survey of name reactions in biological systems. Angew. Chem. Int. Ed. 2017, 56, 3446-3489. [CrossRef] [PubMed]

94. Jeon, B.-s.; Ruszczycky, M.W.; Russell, W.K.; Lin, G.-M.; Kim, N.; Choi, S.-h.; Wang, S.-A.; Liu, Y.-N.; Patrick, J.W.; Russell, D.H.; et al. Investigation of the mechanism of the SpnF-catalyzed [4+2]-cycloaddition reaction in the biosynthesis of spinosyn A. Proc. Natl. Acad. Natl. USA 2017, 114, 10408-10413. [CrossRef] [PubMed]

95. Cavelier, F.; Gomez, S.; Jacquier, R.; Verducci, J. Deracemization of silyl enol ethers. Tetrahedron Asymmetry 1993, 4, 2501-2505. [CrossRef]

96. Cavelier, F.; Gomez, S.; Jacquier, R.; Verducci, J. A first approach to asymmetric protonation via a polymer supported chiral proton donor. Tetrahedron Lett. 1994, 35, 2891-2894. [CrossRef]

97. Diba, A.K.; Noll, C.; Richter, M.; Gieseler, M.T.; Kalesse, M. Intramolecular stereoselective protonation of aldehyde-derived enolates. Angew. Chem. 2010, 122, 8545-8547. [CrossRef]

98. Mohr, J.T.; Hong, A.Y.; Stoltz, B.M. Enantioselective protonation. Nat. Chem. 2009, 1, 359-369. [CrossRef] [PubMed]

99. Bruker. Bruker APEX3, SAINT+ and SADABS; Bruker AXS Inc.: Madison, WI, USA, 2016.

100. Sheldrick, G. SHELXT-Integrated space-group and crystal-structure determination. Acta Crystallogr. 2015, A71, 3-8. [CrossRef] [PubMed]

101. Sheldrick, G. Crystal structure refinement with SHELXL. Acta Crystallogr. 2015, C71, 3-8.

102. Macrae, C.F.; Bruno, I.J.; Chisholm, J.A.; Edgington, P.R.; McCabe, P.; Pidcock, E.; Rodriguez-Monge, L.; Taylor, R.; van de Streek, J.; Wood, P.A. Mercury CSD 2.0-New features for the visualization and investigation of crystal structures. J. Appl. Crystallogr. 2008, 41, 466-470. [CrossRef]

103. Nagao, Y.; Hagiwara, Y.; Tohjo, T.; Hasegawa, Y.; Ochiai, M.; Shiro, M. Highly enantioselective Claisen-type acylation and Dieckmann annulation. J. Org. Chem. 1988, 53, 5983-5986. [CrossRef]

104. Preparation of the racemic reference compound rac-12 was performed according to the general procedures outlined in Scheme 2, replacing (+)-Simpkin's base with LDA to obtain rac-9 for the synthetic sequence.

105. The publCIF document accompanying compound 12-DNB is uploaded as separate file and the structure is deposited at Cambridge Crystallographic Data Centre and identified as CCDC 1535632.

Sample Availability: Samples of exo-mucosin $\left(\mathbf{1}^{*}\right)$ and methyl ester $\mathbf{2}^{*}$ are available from the authors.

(C) 2017 by the authors. Licensee MDPI, Basel, Switzerland. This article is an open access article distributed under the terms and conditions of the Creative Commons Attribution (CC BY) license (http:/ / creativecommons.org/licenses/by/4.0/). 